\title{
Impact of melt ponds on Arctic sea ice simulations from 1990 to 2007
}

Article

Published Version

Flocco, D., Schroeder, D., Feltham, D. L. and Hunke, E. C. (2012) Impact of melt ponds on Arctic sea ice simulations from 1990 to 2007. Journal of Geophysical Research, 117 (C9). ISSN 0148-0227 doi: https://doi.org/10.1029/2012JC008195 Available at https://centaur.reading.ac.uk/30718/

It is advisable to refer to the publisher's version if you intend to cite from the work. See Guidance on citing.

Published version at: http://dx.doi.org/10.1029/2012JC008195

To link to this article DOI: http://dx.doi.org/10.1029/2012JC008195

All outputs in CentAUR are protected by Intellectual Property Rights law, including copyright law. Copyright and IPR is retained by the creators or other copyright holders. Terms and conditions for use of this material are defined in the End User Agreement.

\section{www.reading.ac.uk/centaur}

\section{CentAUR}

Central Archive at the University of Reading

Reading's research outputs online 


\title{
Impact of melt ponds on Arctic sea ice simulations from 1990 to 2007
}

\author{
Daniela Flocco, ${ }^{1}$ David Schroeder, ${ }^{1}$ Daniel L. Feltham, ${ }^{1}$ and Elizabeth C. Hunke ${ }^{2}$ \\ Received 11 May 2012; revised 26 July 2012; accepted 16 August 2012; published 27 September 2012.
}

[1] The extent and thickness of the Arctic sea ice cover has decreased dramatically in the past few decades with minima in sea ice extent in September 2007 and 2011 and climate models did not predict this decline. One of the processes poorly represented in sea ice models is the formation and evolution of melt ponds. Melt ponds form on Arctic sea ice during the melting season and their presence affects the heat and mass balances of the ice cover, mainly by decreasing the value of the surface albedo by up to $20 \%$. We have developed a melt pond model suitable for forecasting the presence of melt ponds based on sea ice conditions. This model has been incorporated into the Los Alamos CICE sea ice model, the sea ice component of several IPCC climate models. Simulations for the period 1990 to 2007 are in good agreement with observed ice concentration. In comparison to simulations without ponds, the September ice volume is nearly $40 \%$ lower. Sensitivity studies within the range of uncertainty reveal that, of the parameters pertinent to the present melt pond parameterization and for our prescribed atmospheric and oceanic forcing, variations of optical properties and the amount of snowfall have the strongest impact on sea ice extent and volume. We conclude that melt ponds will play an increasingly important role in the melting of the Arctic ice cover and their incorporation in the sea ice component of Global Circulation Models is essential for accurate future sea ice forecasts.

Citation: Flocco, D., D. Schroeder, D. L. Feltham, and E. C. Hunke (2012), Impact of melt ponds on Arctic sea ice simulations from 1990 to 2007, J. Geophys. Res., 117, C09032, doi:10.1029/2012JC008195.

\section{Introduction}

[2] The rate of decline of Arctic summer sea ice extent has increased in recent years. Continuous satellite records from 1979 show that the five lowest extents occurred during the last five years (2007 to 2011) (announcement of the National Snow and Ice Data Center [1998], updated 2006). Estimates of sea ice thickness based on satellite altimetry [Laxon et al., 2003; Giles et al., 2008] reveal a reduction in ice thickness, too. It has been suggested that 2010 had the lowest Arctic sea ice volume since records began [Schweiger et al., 2011]. Ensemble climate prediction studies using Global Climate Models (GCMs), such as the Intergovernmental Panel on Climate Change (IPCC) AR4 study, are unable to simulate the observed rapid reduction of sea ice extent [Stroeve et al., 2007]. This shortcoming suggests a need for model improvements.

\footnotetext{
${ }^{1}$ Centre for Polar Observation and Modelling, Department of Earth Sciences, University College London, London, UK.

${ }^{2}$ T-3 Fluid Dynamics and Solid Mechanics Group, Los Alamos National Laboratory, Los Alamos, New Mexico, USA.

Corresponding author: D. Flocco, Centre for Polar Observation and Modelling, Department of Earth Sciences, University College London, Gower Street, London WC1E 6BT, UK. (d.flocco@ucl.ac.uk)

Published in 2012 by the American Geophysical Union.
}

[3] Global warming is intensified in polar regions due to the albedo feedback mechanism [Intergovernmental Panel on Climate Change, 2007]. The importance of the albedofeedback mechanism to the evolution of the sea ice cover presents a problem for GCM simulations because they do not explicitly represent melt ponds on the surface of sea ice. As the melt season progresses, parts of the snow and sea ice surface meltwater produced accumulates to form melt ponds that can cover up to 50 to $60 \%$ of the sea ice surface [Fetterer and Untersteiner, 1998; Eicken et al., 2004]. On flat firstyear ice the melt pond fraction can even rise up to $90 \%$ [Perovich et al., 2011]. The albedo of pond-covered ice, measured to be 0.1-0.5 [Perovich et al., 2002; Eicken et al., 2004], is much lower than that of bare ice and snow covered ice, which are $0.6-0.65$ and $0.84-0.87$, respectively [Perovich and Tucker, 1997]. Since the ice concentration in the interior Arctic is high $(>85 \%)$, melt ponds contribute significantly to the area-averaged albedo [Eicken et al., 2004; Maslanik et al., 2007; Perovich et al., 2007]. Because GCMs do not include melt ponds, they often tune the albedo to produce realistic ice extents [e.g., Eisenman et al., 2007]. However, this tuning takes no account of the changing nature, and particularly the changing topography, of the ice cover [Kwok et al., 2009], or of natural variability.

[4] Field observations of melt ponds provide information on how ponds form and evolve throughout the melt season, until they freeze over in autumn. Melt ponds are typically 5 to $10 \mathrm{~m}$ wide and 15 to $50 \mathrm{~cm}$ deep [Perovich et al., 2009]. Dye 
tracer experiments [e.g., Eicken et al., 2002], demonstrate that surface meltwater can travel horizontally several hundred meters to reach topographic lows. Recently, Polashenski et al. [2012] have presented high resolution observations of pond evolution that provide fresh insight into the mechanisms of meltwater transport and drainage. Optical measurements show that pond-covered ice transmits 3-5 times more solar radiation to the ocean than bare ice [Perovich, 2005]. The melt rate beneath pond-covered ice is up to three times greater than that of bare ice. Shallow ponds covering a large area enhance the total melting rate of the sea ice more than the same volume of meltwater distributed into deeper ponds with smaller area [e.g., Eicken et al., 2004; Lüthje et al., 2006; Scott and Feltham, 2010].

[5] Due to different spectral properties between ponded sea ice, bare sea ice and snow covered sea ice, pond fraction can be derived from remote sensing data [Grenfell and Maykut, 1977]. Examples of pond determination from different satellite data were published by e.g., Markus et al. [2003] and Tschudi et al. [2008]. Rösel et al. [2012] have presented the first Arctic-wide multiannual pond data based on MODIS satellite data.

[6] Various attempts have been made to model melt ponds. Taylor and Feltham [2004] developed a one-dimensional model of melt ponds which calculates the heat and salt balance and includes a two stream radiation model. Lüthje et al. [2006] developed a model to simulate the area evolution of ponds. The sea ice floe is divided into square cells, inside which pond height and ice depth evolve according to the state of the surrounding cells. Skyllingstad et al. [2009] developed a model for melt pond area on level ice. Scott and Feltham [2010] combined the Taylor and Feltham [2004] and Lüthje et al. [2006] models, and introduced many improvements to develop a high fidelity model of melt pond evolution that was used to explore the dependence of melt pond area on topography and snow cover. Polashenski et al. [2012] provides pond-scale observations with which the Scott and Feltham model may be constrained and validated. This opens up the possibility of developing a more physically realistic melt pond model in the future. Flocco and Feltham [2007] developed the first physically based model of melt ponds for use in the sea ice component of a GCM. Flocco et al. [2010] implemented the melt pond scheme into CICE and performed simulations demonstrating the strong impact of the melt pond representation on the predicted sea ice thickness and extent. While Flocco et al.'s simulations were designed to explore the role that melt ponds play in determining the mass balance of the sea ice, our study investigates the fidelity of CICE simulations using our melt pond scheme.

[7] In section 2 the sea ice model CICE and our melt pond scheme are introduced and new developments of the pond scheme are presented. Section 3 describes our model configuration and the applied forcing data. The results are presented in Section 4. In section 4.1 the simulated pond evolution and distribution are shown. The simulated sea ice extent, sea ice concentration and sea ice thickness of the reference run are verified with remote sensing data in section 4.2. Sensitivity studies in section 4.3 investigate the impact on the ice cover of the melt pond scheme, the choice of optical ice properties, the critical lid depth, the maximum pond area, the number of ice thickness categories and the amount of snowfall. Section 4.4 focuses on the simulation of the minimum ice extent in
September 2007. In section 5, we present a discussion and concluding remarks.

\section{Model Description}

\subsection{CICE}

[8] The Los Alamos sea ice model CICE is a dynamicthermodynamic sea ice model designed for inclusion within a GCM. In its standard configuration, CICE includes 5 ice thickness categories. The sea ice velocity is calculated from a momentum balance equation that accounts for air drag, ocean drag, Coriolis force, sea surface tilt, and the (divergence of) internal ice stress. The internal ice stress is calculated using the viscous plastic rheology of Hibler [1979], with artificial elasticity included to aid the solution procedure [Hunke and Dukowicz, 1997]. The redistribution of ice thickness in ridging follows the work of Rothrock [1975]. For further details, see Lipscomb et al. [2007].

[9] The CICE model solves one-dimensional, vertical heat balance equations for each thickness category and snow, if it is present. The sea ice heat balance equation is nonlinear to account for brine content within the sea ice, and contains a source term to account for absorbed solar radiation, and is based on the model of Maykut and Untersteiner [1971] using the energy conserving scheme of Bitz and Lipscomb [1999]. The upper sea ice boundary condition consists of a balance of shortwave, longwave, sensible, latent, and conductive heat fluxes when the ice surface is below freezing. When the surface temperature warms to the melting temperature, it is held at the melting temperature and the flux imbalance drives melting through a moving boundary (Stefan) condition. No surface freezing is possible. The lower sea ice boundary conditions are that the ice temperature is set equal to the freezing temperature, and a Stefan condition is used to determine either melting or freezing dependent on the difference between the conductive heat flux in the ice toward the atmosphere and the turbulent oceanic heat flux into the ice.

[10] The version of CICE chosen in this work, version 4.1, uses the Delta-Eddington multiple scattering radiative transfer model [Briegleb and Light, 2007]. Albedo values for bare ice, snow and ponded ice are not prescribed but calculated from inherent optical properties: extinction coefficient, single scattering albedo and asymmetry properties, which can be determined from physical measurements of shape, number, and size of ice and snow grains as well as brine, gas and precipitated salts.

\subsection{Our Melt Pond Scheme}

[11] When meltwater forms due to snow and surface ice melt, it runs downhill under the influence of gravity. Thus, the topography of the ice cover plays a crucial role in determining the melt pond cover [e.g., Eicken et al., 2004; Lüthje et al., 2006; Scott and Feltham, 2010]. In common with all sea ice models within a GCM, CICE does not explicitly represent the topography of sea ice. CICE uses a discretized ice thickness distribution function [Thorndike et al., 1975] with five ice categories in the reference configuration. We assume that each sea ice thickness category is in hydrostatic equilibrium at the beginning of the melt season, so that the sea ice thickness distribution function can be split into a surface height and basal depth distribution. For our melt pond parameterization, we then calculate the position of sea level 
assuming that the ice in the whole grid cell is rigid and in hydrostatic equilibrium. The principle for meltwater distribution within a given grid cell and time step is, then, to take the volume of meltwater (suitably modified by advection, precipitation, melting, freezing, drainage and run-off) and cover the ice thickness categories in order of increasing surface height (accounting for saturated snow, where present) [Flocco et al., 2010].

[12] As meltwater accumulates on the ice cover, a prescribed fraction (we chose $15 \%+70 \% \times\left(1-A_{\text {ice }}\right.$ ) with ice concentration $A_{\text {ice }}$ based on Holland et al. [2012]) runs off the edges of the floes or through cracks. The remaining meltwater sits on the ice surface and may drain vertically through the ice and into the ocean while the hydraulic head is positive (the pond surface is above sea level). The location of sea level with respect to the ice surface is calculated at each time step from a hydrostatic balance. The vertical drainage of meltwater through the sea ice and into the ocean is calculated using Darcy's Law for flow through a permeable medium. As proposed by Golden et al. [2007] the vertical permeability of sea ice $\Pi$ (unit $\mathrm{m}^{2}$ ) can be calculated from the solid fraction $\phi$ :

$$
\Pi=3(1-\phi)^{3} \times 10^{-8}
$$

[13] Since the solid fraction varies throughout the depth of the sea ice, so does the permeability. The rate of vertical drainage is determined by the lowest (least permeable) layer, corresponding to the highest solid fraction. From the equations describing sea ice as a mushy layer [Feltham et al., 2006], the solid fraction is determined by:

$$
\phi=\frac{c_{b u l k}-C(T)}{c_{i}-C(T)}
$$

where $c_{\text {bulk }}$ is the bulk salinity of the ice (3.2 ppt in this work), $C(T)$ is the concentration of salt in the brine at temperature $T$ and $c_{i}$ is the concentration of salt in the ice crystals (set to zero).

[14] When the surface energy budget of a melt pond becomes negative, the pond will cool down. It can be shown [e.g., Taylor and Feltham, 2004] that ponds of all reasonable depths (up to 2-3 m) will reach the freezing temperature within a couple of hours. In our pond scheme, we assume that a layer of ice starts forming at its upper surface immediately when the energy balance is negative. The growth rate of the ice lid $\left(H_{u i}\right)$ is calculated by the Stefan energy budget at the lid-pond interface with a linear approximation for the temperature gradient in the ice lid:

$$
H_{u i}=\sqrt{\frac{2 k_{i}}{\rho_{s} L} \Delta T_{i c e} t^{\frac{1}{2}},}
$$

where $k_{i}$ is the thermal conductivity of the ice lid, $\rho_{s}$ is the ice density, $L$ is the latent heat of fusion, $\Delta \mathrm{T}$ is the temperature difference between the top and the bottom of the lid, and $t$ is time. Depending on the surface flux conditions the ice lid can grow, partially melt, or melt completely. Provided that the ice lid is thinner than a critical lid depth $(1 \mathrm{~cm}$ in our reference run) then the pond is regarded as effective, i.e., the pond affects the optical properties of the ice cover. Effective pond area and pond depth for each thickness category are passed to the radiation scheme for calculating albedo. Note that once the ice lid has exceeded the critical thickness, snow may accumulate on the lid causing a substantial increase in albedo.

[15] See Flocco et al. [2010] for more details about the pond scheme in CICE and Flocco and Feltham [2007] for the continuum model of melt ponds.

\subsection{New Developments of Melt Pond Model}

[16] In comparison to our previous work [Flocco et al., 2010] the following additional features have been implemented into the melt pond model. Pond volume, pond area and lid volume are transported as tracers on each ice thickness category. While all three quantities can be modified by advection, the total pond volume is preserved on each grid cell when sea ice is redistributed between ice categories. At each time step our pond scheme accounts for the new thickness distribution in redistributing the pond volume. Thus, changes in pond coverage due to changes in thickness distribution are accounted for.

[17] The sea ice area can shrink due to melting and due to ridging. In both cases, the pond volume over the lost area is released to the ocean immediately. We prescribe the maximum fraction that can be covered by ponds in each ice category as a function of ice thickness $h_{\text {ice }}$ as $83.2 \%$ $h_{\text {ice }} * 2.4 \%$, which was obtained from a fit of pond fraction to ice thickness from a series of high resolution simulations with a floe-scale melt pond model [Lüthje et al., 2006].

[18] In the current CICE model the melt ponds do not affect the thermodynamics of the ice model except through altering the albedo. If the heat balance is negative, a lid is forming. Only while the lid depth is below a critical value of $1 \mathrm{~cm}$ are optical properties of ponded sea ice applied. While the lid is forming, sea ice beneath the pond starts growing simultaneously in the model. In reality until the pond has refrozen the rate of basal freezing is limited because it is not possible for a negative temperature gradient to form throughout the whole ice depth, required to transport latent heat released in basal freezing to the atmosphere. To conserve energy, the ice lid is dismissed once the pond is completely refrozen.

\section{Model Configuration}

\subsection{Setup of Reference Simulation}

[19] An overview of the setup of our reference CICE simulation is given in Table 1. All parameters are set to standard values. While the CICE simulations of Flocco et al. [2010] were designed to explore the role that melt ponds play in determining the mass balance of the sea ice, our study investigates the fidelity of CICE simulations using our melt pond scheme.

[20] The simulation domain covers the whole Arctic and the northern North Atlantic (see, e.g., Figure 1). While the Hudson Bay and some of the Northwestern Passages are filled, the main passage of the Northwestern Passages and the Nares Strait are open. The grid is based on the ORCA1 tripolar grid developed for the NEMO ocean model with a horizontal resolution of approx. $40 \mathrm{~km}$ [Madec, 2008]. Stand-alone sea-ice simulations are performed for the period 1980 to 2007 with a homogeneous initial ice thickness of $2.5 \mathrm{~m}$, a snow depth of $20 \mathrm{~cm}$ and an ice concentration of $100 \%$. After a spin up period of 10 years, the ice conditions are fully independent of the initial conditions. Results from the period 1990 to 2007 are evaluated. 
Table 1. Setup for Our CICE Reference Simulation

\begin{tabular}{lc}
\hline \multicolumn{1}{c}{ Radiation } & $\begin{array}{c}\text { Delta-Eddington Scheme } \\
\text { [Briegleb and Light, 2007] }\end{array}$ \\
\hline Advection & Linear remapping scheme \\
Atmospheric Drag & $\begin{array}{c}\text { Roughness length: } 5 \times 10^{-4} \mathrm{~m}, \\
\text { stability dependent }\end{array}$ \\
Ocean Drag & Minimum friction velocity: \\
& $5 \times 10^{-4} \mathrm{~ms}^{-1}$ \\
Ice categories & 5 thickness classes (limits: $0.6 \mathrm{~m}$, \\
& 1.4 m, $2.5 \mathrm{~m}, 4.6 \mathrm{~m})$ \\
Melt pond scheme & Flocco et al. $[2010]$ with our new \\
& developments \\
Rheology & EVP with Rothrock [1975] pressure \\
& formulation (ratio of ridging to PE \\
change: 17, e-folding scale \\
of ridged ice: 4$)$
\end{tabular}

\subsection{Forcing Data}

[21] Atmospheric forcing data include 6-hourly $2 \mathrm{~m}$ air temperature, $2 \mathrm{~m}$ humidity and $10 \mathrm{~m}$ wind velocity, daily downward shortwave and longwave radiation fluxes and monthly rainfall and snowfall from the ERA-40 based Drakkar Forcing Set DFS4.1 [Brodeau et al., 2010]. Comparing monthly climatological means (1979-1993) of the downward shortwave flux with OMIP (Ocean Modeling Intercomparison Project) Version 4 data [Röske, 2005] reveals major regional differences. In the central Arctic the DFS fluxes are 10-40\% larger than the OMIP fluxes in June, July and August, while over the northern North Atlantic the OMIP fluxes are larger (see Figure 1). In order to obtain realistic simulations, we multiplied the daily Drakkar shortwave radiation fluxes by correction factors calculated from the OMIP climate monthly mean divided by the Drakkar climate monthly mean (Figure 1). This approach preserves the daily variability of the Drakkar data on the one hand with the more realistic OMIP climatology on the other hand.

[22] CICE contains a simple mixed layer ocean model with a prognostic ocean temperature. The turbulent heat flux from the deeper ocean into the mixed layer is prescribed with climatological monthly means taken from a Community Climate System Model (CCSM) climate run (b30.009) [Collins et al., 2006] (Figure 2). Negative heat fluxes, which occur in some regions during summer, are set to zero to avoid cooling of the mixed layer. Climatological monthly means from MYO-WP4-PUM-GLOBAL-REANALYSISPHYS-001-004 [Ferry et al., 2011] are used for the mixed layer salinity (depth of $3 \mathrm{~m}$ ) and the ocean current (depth of $23 \mathrm{~m}$ ) (Figure 3). The initial ocean temperature is also taken from the same reanalysis product.

\section{Results}

\subsection{Pond Evolution}

[23] Figure 4a shows the annual evolution of Arctic mean pond area (fraction of sea ice area) as simulated in our reference run. Melt ponds start to form at the end of May, a maximum extent of nearly $20 \%$ is reached in the climatological mean at mid-July, and nearly all ponds are covered with an ice lid by mid-August. The total pond area, including ponds which are covered by a lid but not fully frozen to the bottom, reaches a maximum of $33 \%$. But only by the end of September is the pond water completely refrozen. The time series of individual years document a strong interannual variability (Figure 4b). In 1996, the year with maximum summer ice extent, the maximum Arctic mean pond area reaches only $14 \%$. In 2007 , the year with minimum summer ice extent, the pond area fraction is larger with a first maximum fraction of $23 \%$ in the second half of June and a second maximum of $22 \%$ at mid-July. In between a colder weather period causes some of the ponds to refreeze at their upper surface. It is striking that 2007 is the year in which ponds form earlier than in any other year between 1990 and 2007. That suggests that ponds might play a role in the 2007 event of minimum ice extent.

[24] In a climatological July - the month of the maximum Arctic mean pond fraction - pond area fraction varies spatially from $5 \%$ to $45 \%$ with maximum values along the ice edge and minimum values over the thicker ice north of Canada (Figure $4 \mathrm{c}$ ). The pond depth shows a different pattern. While the average depth is under $30 \mathrm{~cm}$ in most parts of the Arctic Ocean, depths between $30 \mathrm{~cm}$ and $70 \mathrm{~cm}$ occur north of Canada (Figure 4d). Depths of more than $1 \mathrm{~m}$ are simulated during August (not shown). In 2007, pond area fractions of up to $60 \%$ occur in July (Figure $4 \mathrm{e}$ ). The values and the distribution of the pond coverage are reasonable in comparison to existing observation data. Fetterer and Untersteiner [1998] observed higher ponds fractions of up to $60 \%$ on the flat firstyear ice and lower pond fractions on the more irregular surface topography of multiyear ice. The spatial distribution maps of Rösel et al. [2012] show pond fraction values ranging from 20 to $50 \%$ in July and August.

\subsection{Verification of Reference Run}

[25] Before we analyze the impact of the melt pond treatment and other related quantities on the simulated Arctic sea ice, we will investigate how realistic the reference CICE simulation is with our melt pond scheme. Is the strong effect of melt pond presence on simulated sea ice cover shown by Flocco et al. [2010] still valid under more realistic settings? Due to nonlinear feedback processes, sensitivity results are more convincing if simulated ice properties are within the observed range. We apply SSM/I (Special Sensor Microwave/ Imager) passive microwave satellites data calculated using the Bootstrap algorithm [Comiso, 1999] (updated 2008) for sea ice concentration and ERS radar altimetry data [Laxon et al., 2003] for sea ice thickness.

\subsubsection{Sea Ice Extent}

[26] The climatological annual cycle of sea ice extent (the area which is covered by sea ice with a minimum concentration of $15 \%$ ) was calculated from monthly means of CICE and SSM/I ice concentration for the period 1990 to 2007. To enable a meaningful comparison, only the area that is covered by both model and observation is taken into account. The resulting sea ice extent values (see Figure 5a) are therefore smaller than those representing the whole Arctic ice extent, since parts of the Canadian Arctic Ocean and the area near the North Pole are missing. The comparison shows that the simulated range of ice extent is within the observed range apart from the winter months. The winter ice extent in a stand-alone simulation is determined by oceanic heat flux convergence [Bitz et al., 2005], here prescribed as a monthly climatology taken from a CCSM climate simulation (see 

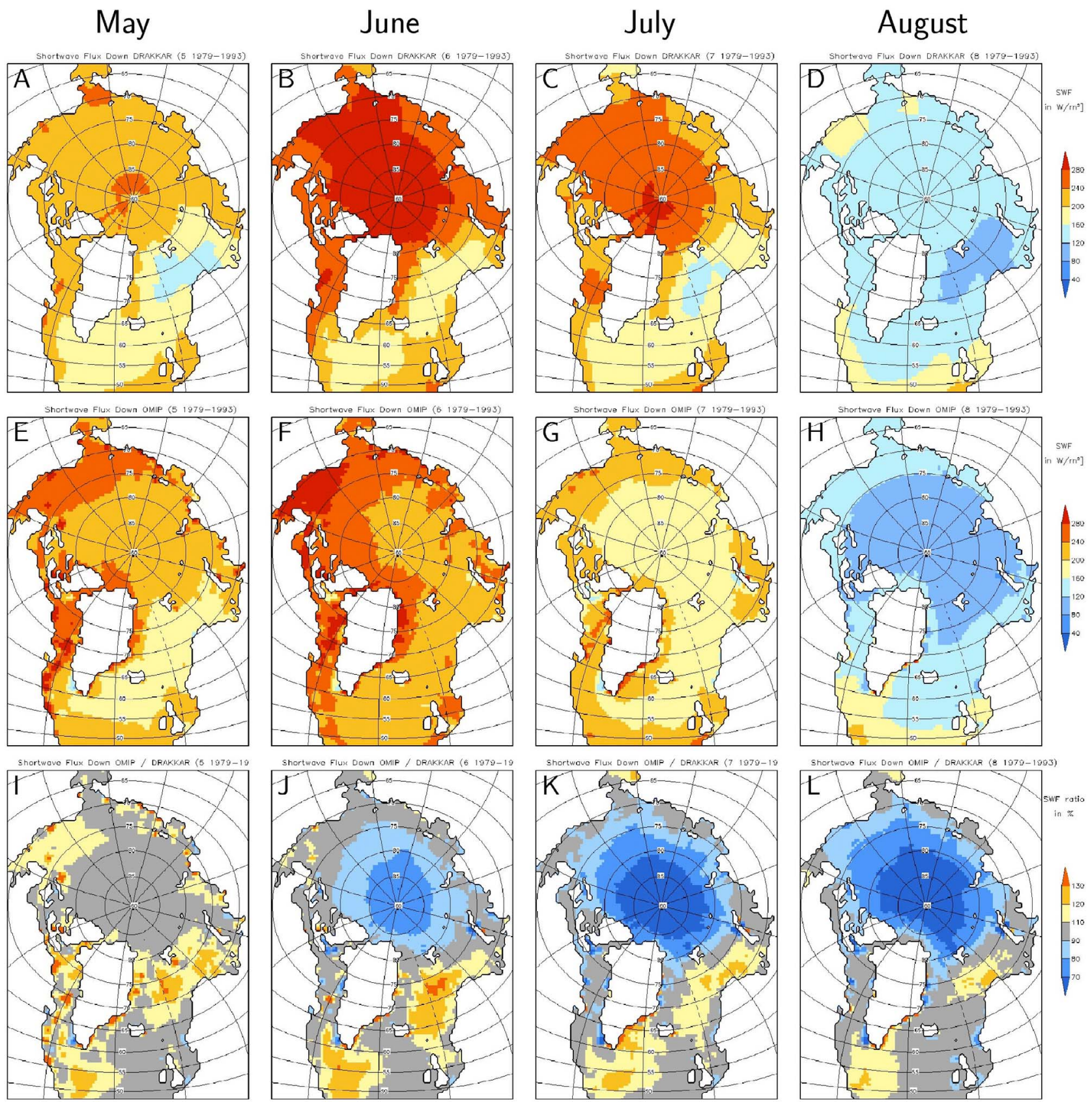

Figure 1. Comparison of climatological shortwave radiation flux SWF (mean over period 1979 to 1993) between DKAKKAR DFS4.1 and OMIP Version 4 data. (a-d) DRAKKAR shortwave flux for May, June, July, and August, (e-h) OMIP shortwave flux, and (i-l) ratio OMIP / DRAKKAR applied as a correction factor for daily DRAKKAR shortwave flux.

section 3.2). Thus, the marginal shortcomings ( $2 \%$ difference) are likely to be caused by the applied ocean heat flux from the CCSM simulation. The simulated range of summer ice extent is narrower than the observed one. Comparing the time series of September ice extent (Figures $5 \mathrm{~b}$ and $5 \mathrm{c}$ ) reveals that the inter-annual variability is captured in our simulation, but the negative trend of the SSM/I ice extent is missing.

\subsubsection{Sea Ice Concentration}

[27] Climatological means of March and September ice concentration are compared with SSM/I observations. In
March, the overestimation of ice concentration in the Fram Strait and in the Barents Sea is associated with an overestimation of ice extent which was discussed in the previous section. In September, the simulated ice concentration is in agreement with the SSM/I ice concentration (i.e., to within $10 \%$, the approximate accuracy of SSM/I data [Kern et al., 2003; Meier, 2005]) for most parts of the Arctic Ocean (Figure 6d). The ice concentration is underestimated along the ice edge north of the Kara Sea, Barents Sea and in the Fram Strait and overestimated north of the Laptev Sea. 

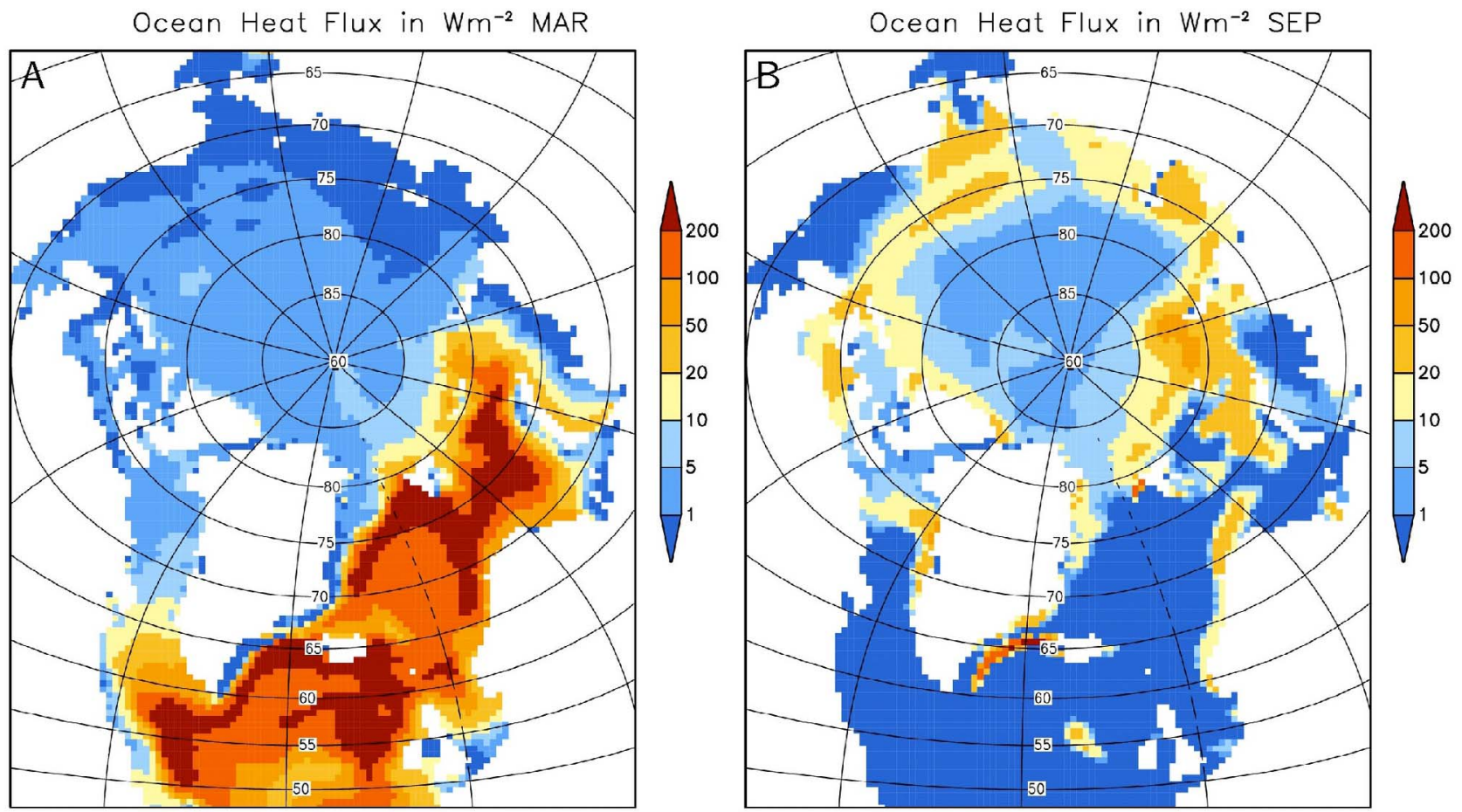

Figure 2. Turbulent ocean heat flux from the deeper ocean into the ocean mixed layer from a Community Climate System Model (CCSM) climate run (b30.009) [Collins et al., 2006]. (a) Climate mean for March and (b) climate mean for September.

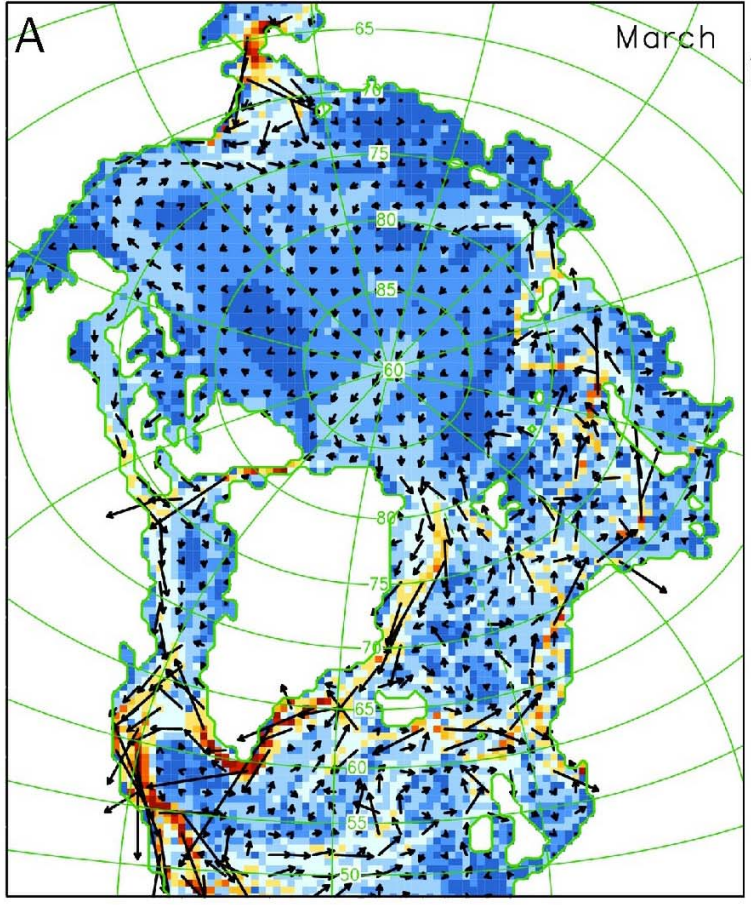

Ocean Current in $\mathrm{cm} / \mathrm{s}$ (every $\underset{30}{\stackrel{\text { (erd }}{\longrightarrow}}$ gridpoint)

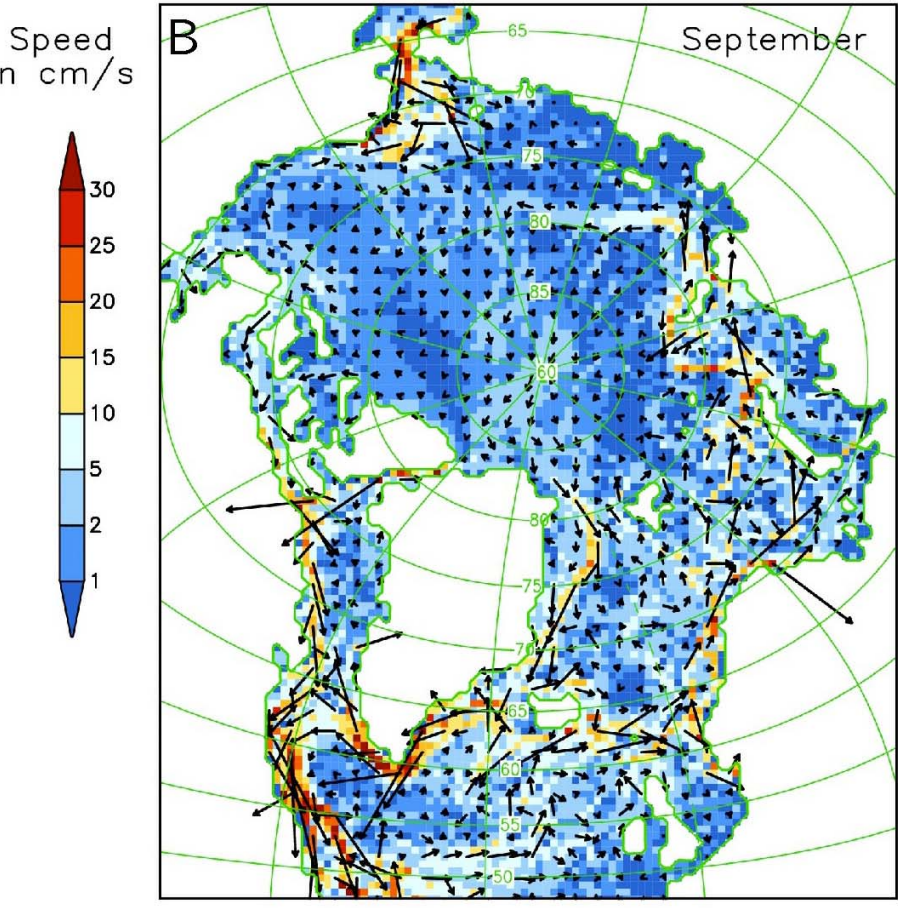

Ocean Current in $\mathrm{cm} / \mathrm{s}$

Figure 3. Ocean Current at $23 \mathrm{~m}$ depth from MYO-WP4-PUM-GLOBAL-REANALYSIS-PHYS-001-004 [Ferry et al., 2011]: (a) climate mean for March and (b) climate mean for September. 

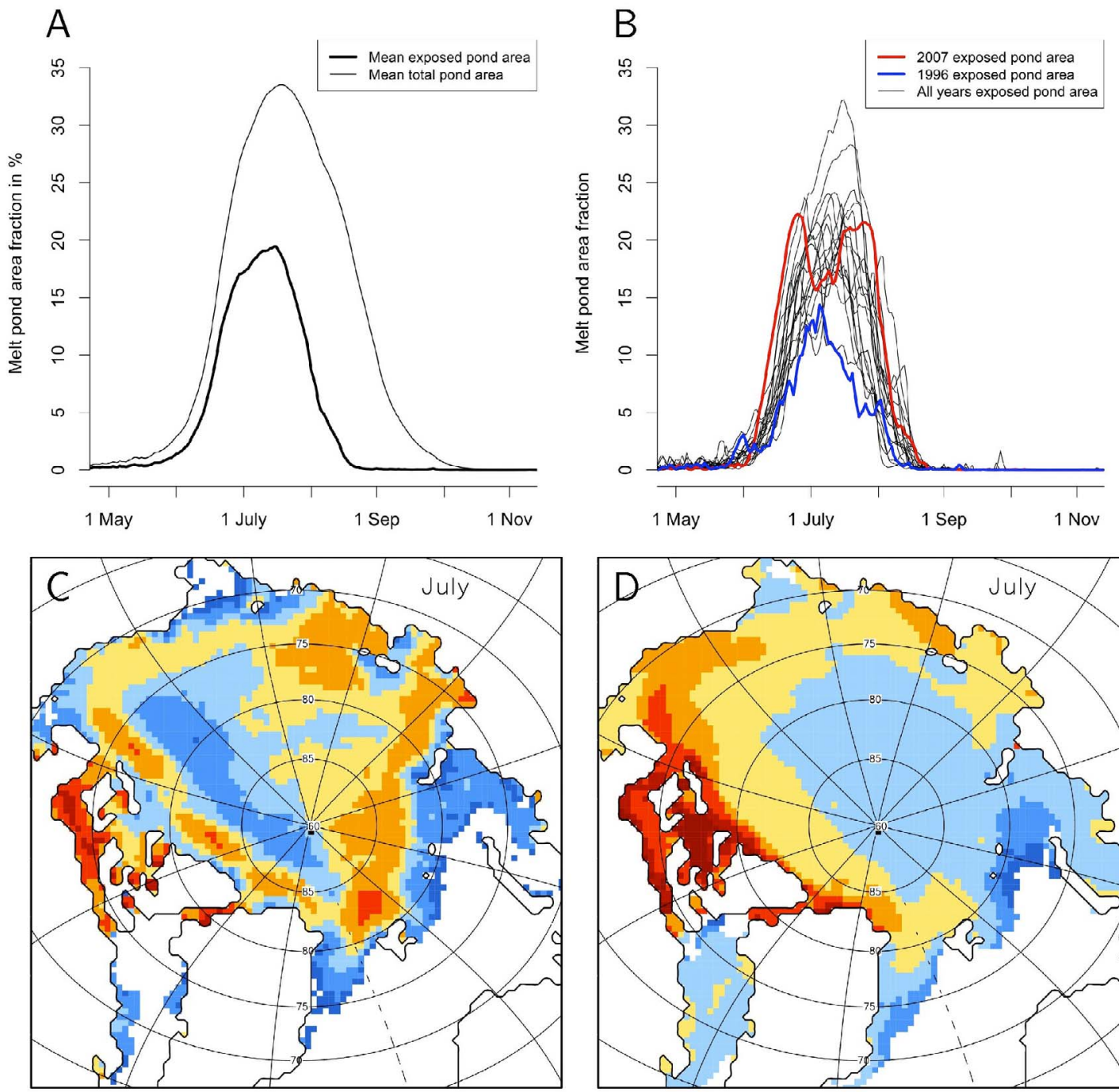

Melt pond open area fraction in \%

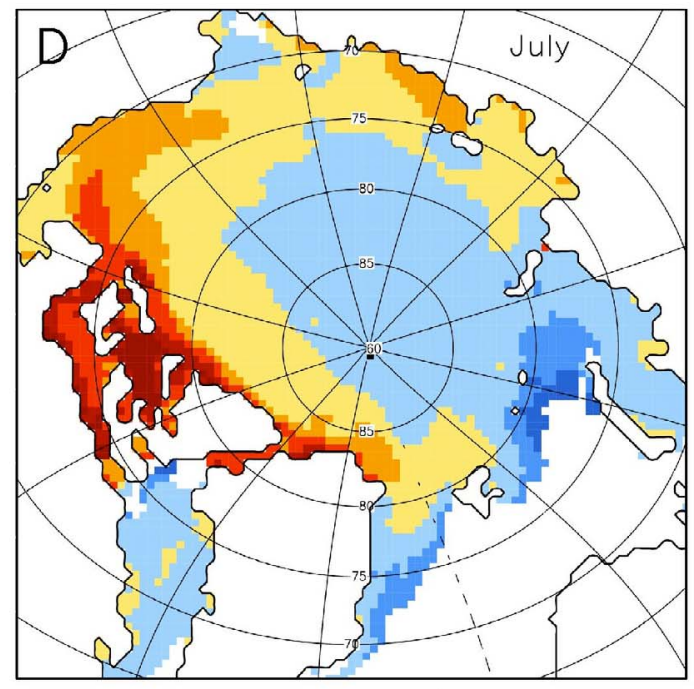

\begin{tabular}{lllllll}
$\frac{1}{5}$ & $\frac{1}{10}$ & $\frac{1}{15}$ & $\frac{1}{20}$ & $\frac{1}{30}$ & $\frac{1}{40}$ & \\
\hline
\end{tabular}
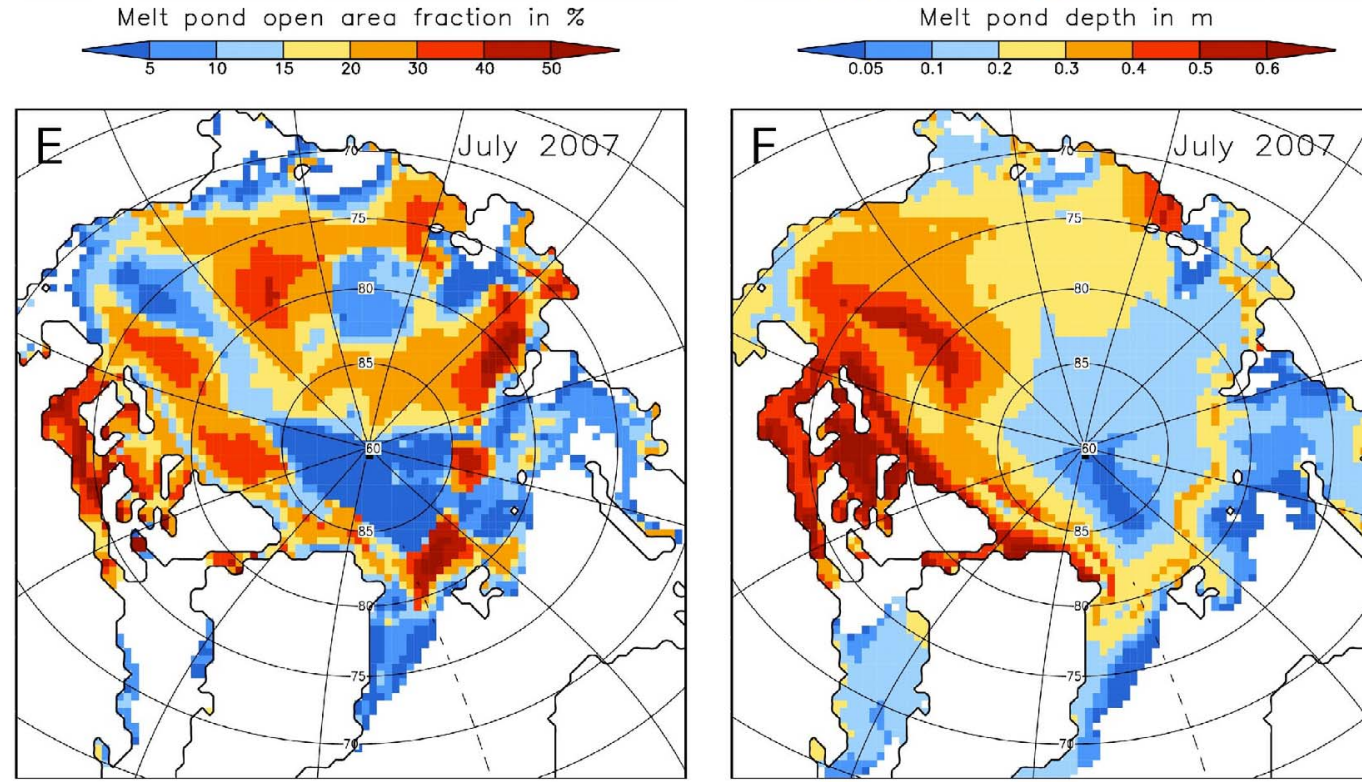

Melt pond open area fraction in \%
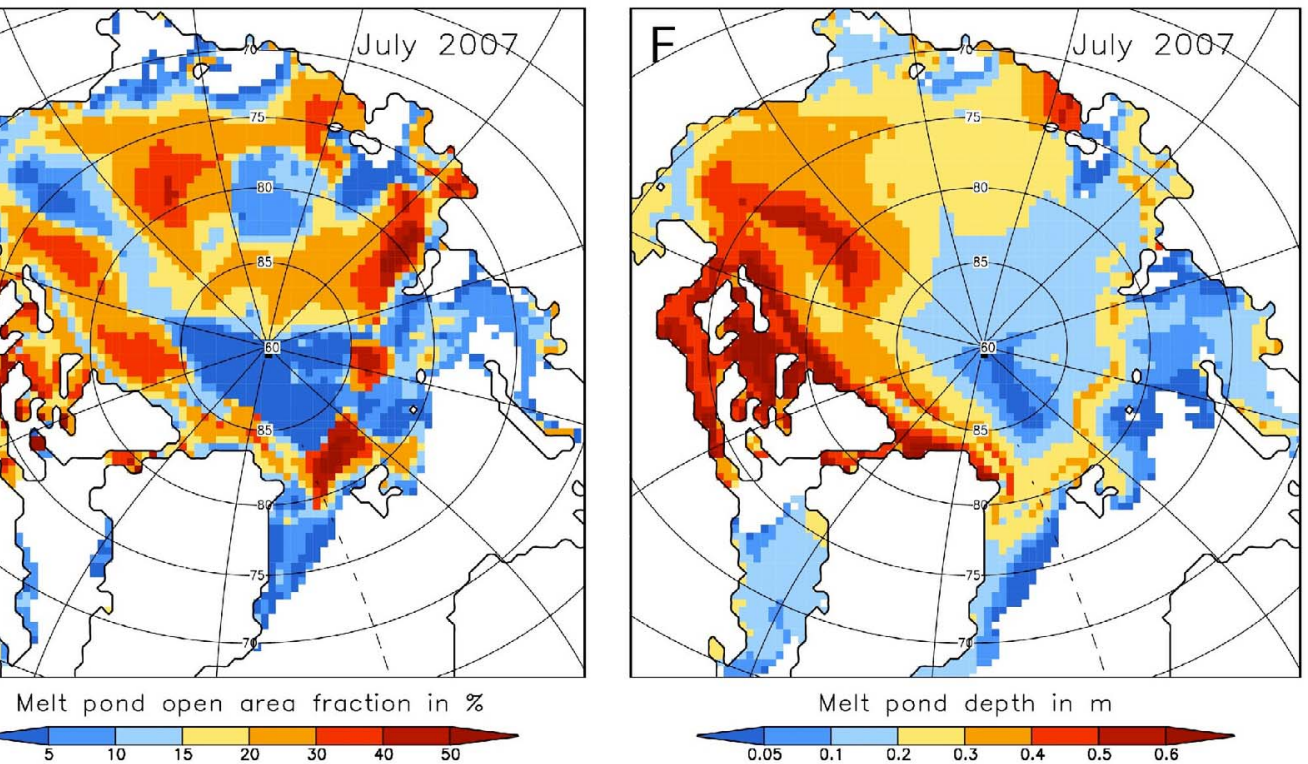

Melt pond depth in $m$

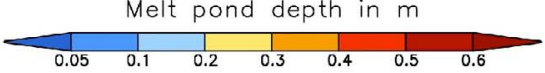

Figure 4

7 of 17 

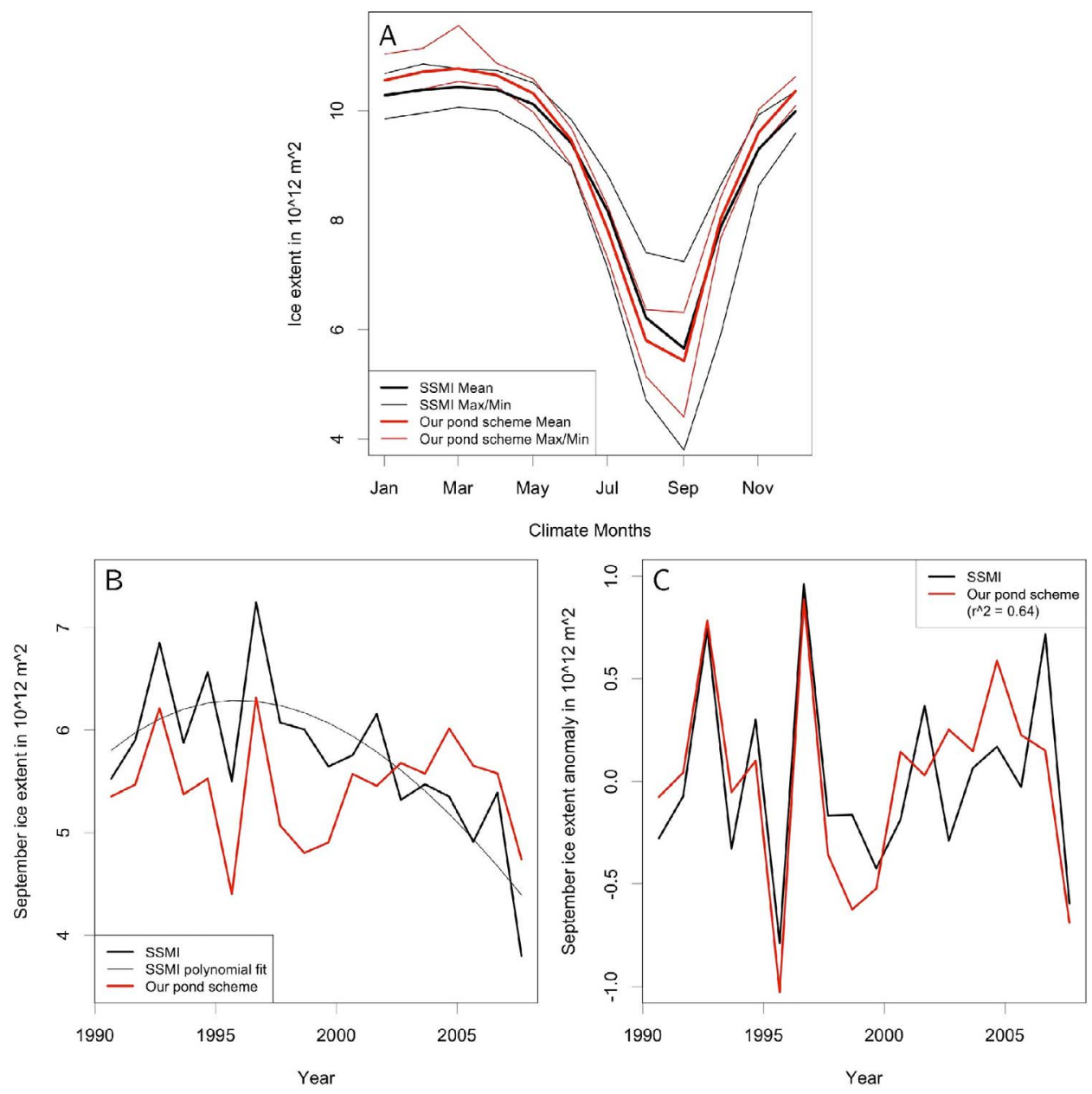

Figure 5. Verification of sea ice extent in CICE reference simulation with our pond scheme by use of SSM/I data: (a) Climatological annual mean cycle with minimum and maximum values. (b) September ice extent from 1990 to 2007 . A polynomial fit of $3^{\text {rd }}$ order is added for the SSM/I extent. (c) September ice extent anomaly from 1990 to 2007. The polynomial fit is subtracted for the SSM/I sea ice extent and the mean for the CICE extent.

\subsubsection{Sea Ice Thickness}

[28] Climatological monthly means of ice thickness are calculated from our simulation over the period 1990 to 2007 and from ERS [Laxon et al., 2003] over the period 1993 to 2003. In March, the ice thickness ranges from $20 \mathrm{~cm}$ in the southern Barents Sea, via $2 \mathrm{~m}$ close to the North Pole, to more than $5 \mathrm{~m}$ along the Canadian coast in our reference simulation (Figure 7a). For most regions this is approximately $1 \mathrm{~m}$ less than is observed (see Figure 7b), although we note that $1 \mathrm{~m}$ is not far above the uncertainty of laser ice thickness retrieval which amounts to $76 \mathrm{~cm}$ (see Giles et al. [2007] for an error analysis). In the Barents Sea and the Fram Strait our simulation underestimates the ERS thickness by $2 \mathrm{~m}$ to $3 \mathrm{~m}$. On the other hand, the ice thickness is overestimated at some parts north of Canada. This is likely to be caused by not resolving all sea passages. In September, the ice is $0.5 \mathrm{~m}$ to $1.5 \mathrm{~m}$ thinner than during winter and apart from a few areas north of Canada is in agreement with the observation.

[29] In general, the climatology of the reference CICE simulation with our melt pond scheme is in good agreement with observed ice extent and concentration and in reasonable agreement with observed ice thickness. The largest discrepancies occur in the Fram Strait, where the ice is too thin and drifts too fast, and in the Barents Sea, but these regions are of minor importance for studying the impact of melt ponds.

\subsection{Sensitivity Studies}

[30] All sensitivity experiments are carried out the same way as the reference run except for the property that is modified. See Table 2 for an overview.

Figure 4. Melt pond area (fraction of sea ice area) and depth in the reference simulation. (a) Annual cycle of exposed pond area for individual years, (b) climatological annual cycle (mean over the period 1990 to 2007) of exposed pond area and total pond area (including lid covered fraction), (c) exposed pond area fraction and (d) pond depth for climatological July, and (e) exposed pond area fraction and (f) pond depth for July 2007. 


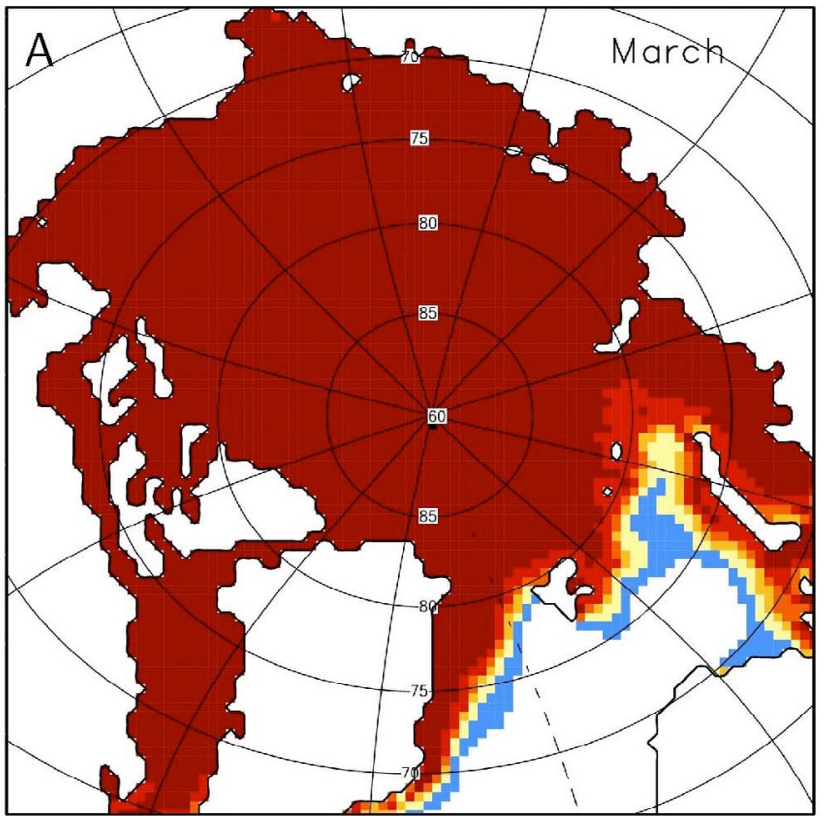

CICE March 2007 lce concentration in \%
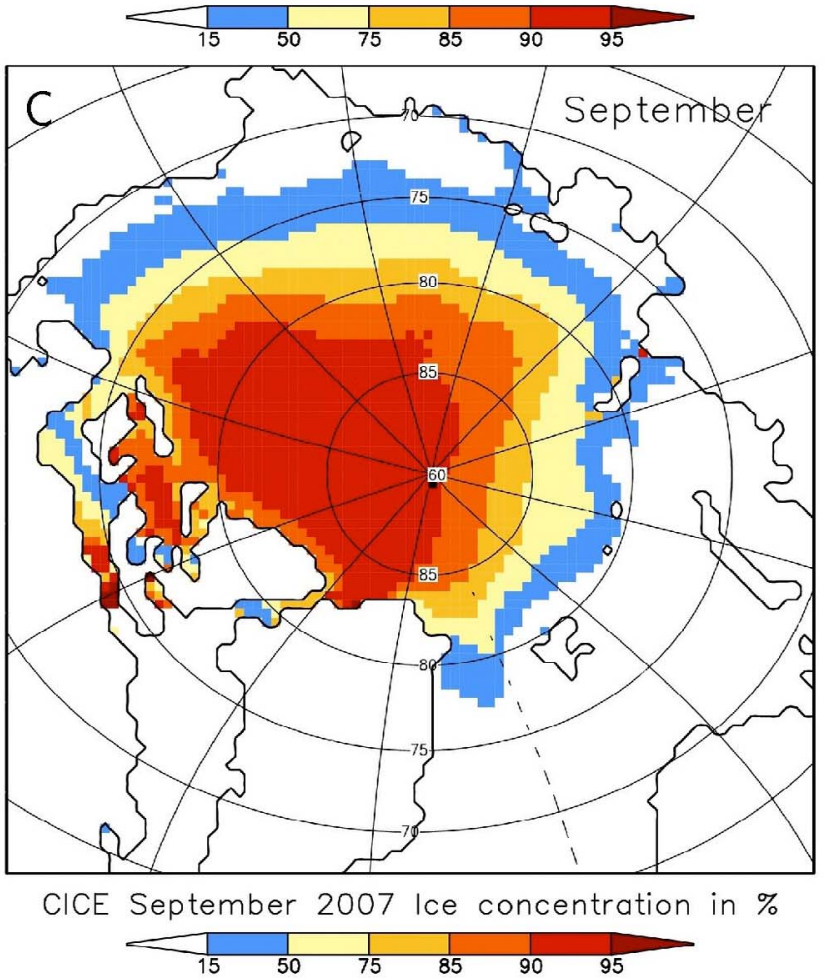

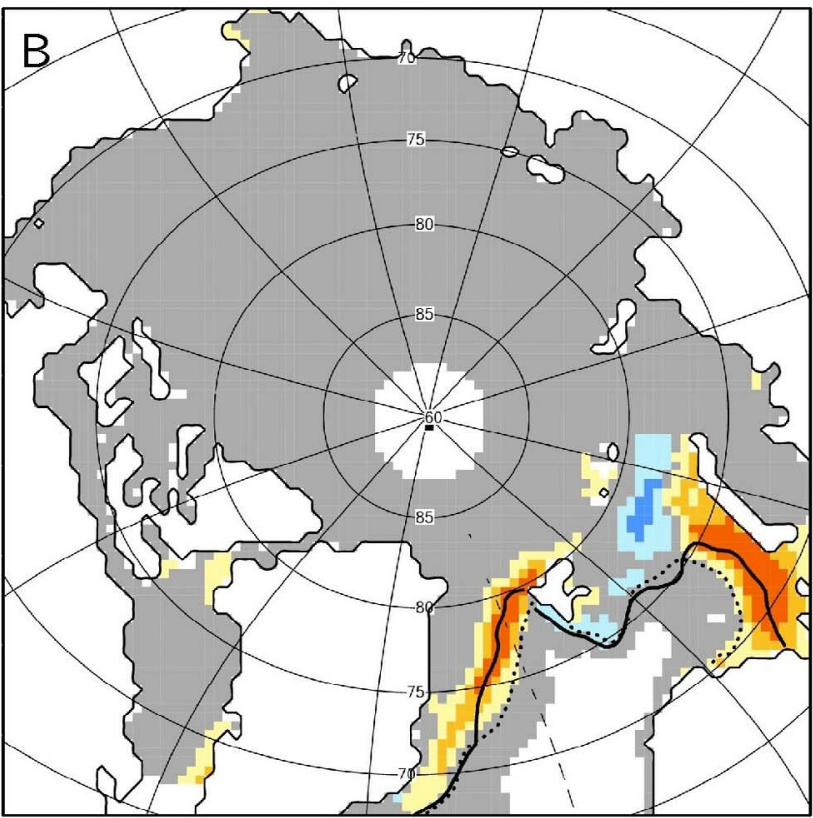

CICE minus SSMI March 2007 lce conc. in \%
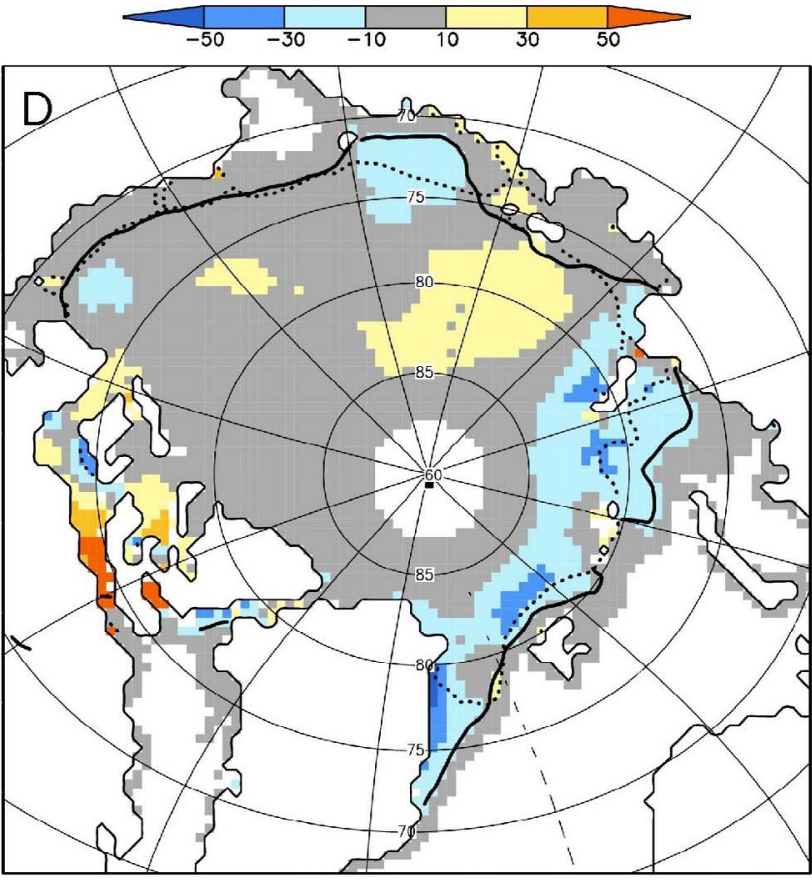

CICE minus SSMI Sept. 2007 Ice conc. in \%

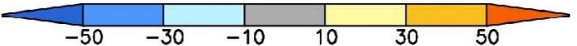

Figure 6. Verification of sea ice concentration in CICE reference simulation with our pond scheme by use of SSM/I data: (a) climatological CICE March ice concentration, (b) difference between CICE and SSM/I March ice concentration, (c) climatological September CICE ice concentration, and (d) difference between CICE and ERS September ice concentration. The continuous line in Figures $6 \mathrm{~b}$ and $6 \mathrm{~d}$ represents the SSM/I ice extent (15\% contour line) and the dotted line the CICE ice extent.

\subsubsection{Impact of Melt Pond Scheme}

[31] What is the impact of the melt pond treatment on simulating the Arctic sea ice? To answer this question, we compare our reference run with three different melt pond approaches. First, we artificially set pond area and volume to zero. Second, we apply the CCSM3 radiation scheme instead of the Delta-Eddington radiation scheme. Melt ponds are not explicitly accounted for, but the albedo is adjusted to observations (e.g., SHEBA experiment [Curry and Schramm, 2001]) that include ponds. Third, we apply the semi-empirical Bailey scheme [Holland et al., 2012] in which pond area and depth are parameterized as a function of the volume of 

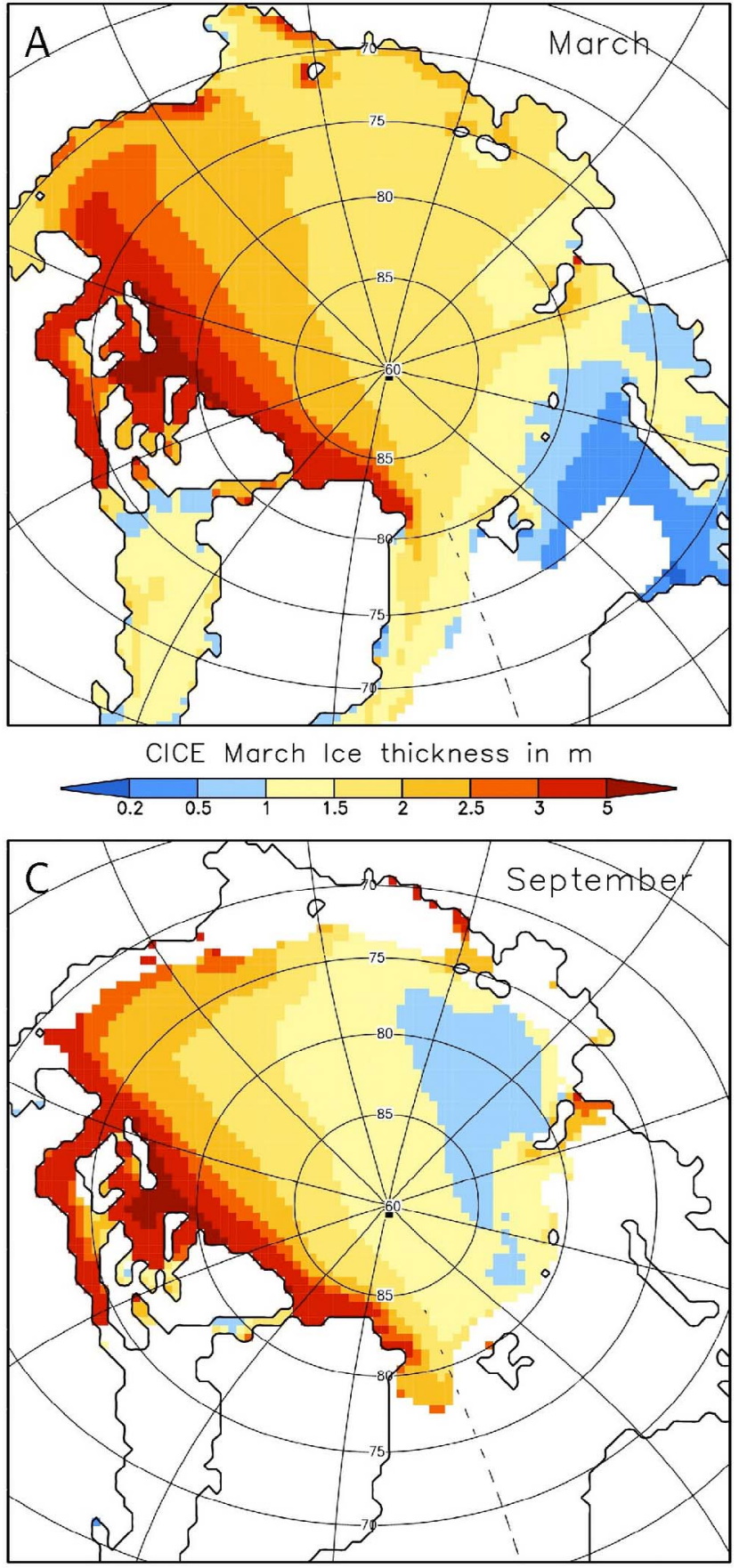

CICE September lce thickness in $\mathrm{m}$

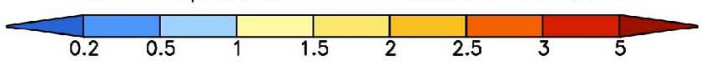

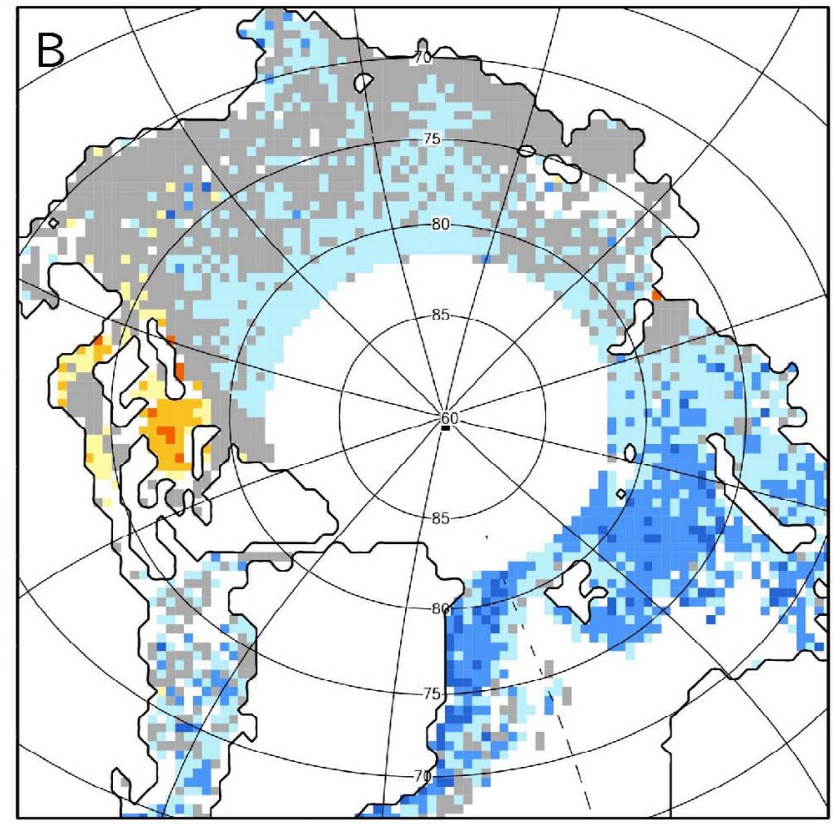

CICE minus ERS March lce Thickness in $\mathrm{m}$
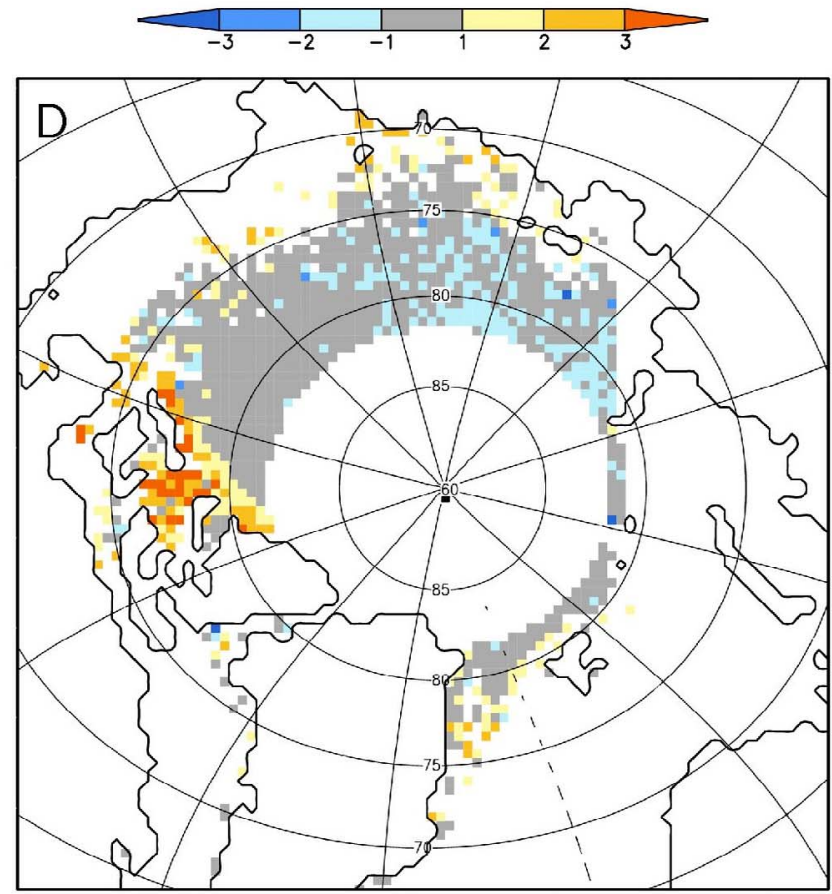

CICE minus ERS Sept. Ice Thickness in $m$

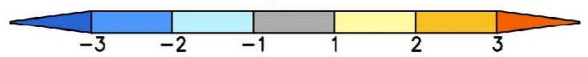

Figure 7. Verification of sea ice thickness in CICE reference simulation with our pond scheme by use of ERS observation data: (a) climatological CICE March ice thickness, (b) difference between CICE and ERS March ice thickness, (c) climatological September CICE ice thickness, and (d) difference between CICE and ERS September ice thickness.

meltwater and the change of meltwater volume as a function of surface temperature [see Flocco et al., 2010, section 2.3].

[32] The climatological annual cycle of sea ice extent shows no differences between the four simulations from October to June (Figure 8a). As expected the strongest impact occurs in September with an average ice extent varying from
$5.3 \times 10^{12} \mathrm{~m}^{2}$ (Semi-Empirical) via $5.4 \times 10^{12} \mathrm{~m}^{2}$ (Our pond scheme) and $5.6 \times 10^{12} \mathrm{~m}^{2}(\mathrm{CCSM})$ to $6.0 \times 10^{12} \mathrm{~m}^{2}$ (No ponds). The impact is smaller than those found in the previous study of Flocco et al. [2010]. Ice thickness and volume are more strongly affected by the melt pond treatment than ice extent (Figure 8b). The September ice volume is $40 \%$ 
Table 2. Overview of All CICE Sensitivity Experiments

\begin{tabular}{|c|c|}
\hline No Ponds & Pond Area and Volume Zero \\
\hline Semi-empirical pond scheme & Bailey [Holland et al., 2012] \\
\hline Implicit ponds & CCSM3 radiation scheme instead of Delta-Eddington \\
\hline Optical properties: $-2 \mathrm{R}$ & $\begin{array}{l}\text { Varying optical properties for bare ice, snow ice and ponded ice by } \\
\text { two standard deviations resulting in an increase of albedo }\end{array}$ \\
\hline Optical properties: $+2 \mathrm{R}$ & $\begin{array}{l}\text { Varying optical properties for bare ice, snow ice and ponded ice by } \\
\text { two standard deviations resulting in a decrease of albedo }\end{array}$ \\
\hline Lid depth: $5 \mathrm{~cm}$ & Increase of critical lid depth from $1 \mathrm{~cm}$ to $5 \mathrm{~cm}$ \\
\hline Lid depth: $2 \mathrm{~mm}$ & Decrease of critical lid depth from $1 \mathrm{~cm}$ to $2 \mathrm{~mm}$ \\
\hline Pond area: $100 \%$ & Maximum pond coverage not limited \\
\hline Pond area: $50 \%$ & Maximum pond coverage limited to $50 \%$ \\
\hline 15 ice categories & $\begin{array}{l}15 \text { ice thickness classes (limits: } 0.2,0.4,0.7,0.9,1.2,1.5,1.9,2.3 \text {, } \\
\quad 2.8,3.5,4.5,5.6,7.2,9.3,11.9 \mathrm{~m})\end{array}$ \\
\hline 3 ice categories & 3 ice thickness classes (limits: $1.1,2.6,7.2 \mathrm{~m}$ ) \\
\hline Snowfall: $+33 \%$ & Monthly snowfall rate increased by $33 \%$ \\
\hline Snowfall: $-33 \%$ & Monthly snowfall rate decreased by $33 \%$ \\
\hline
\end{tabular}

higher in the simulation without ponds in comparison to our pond scheme. The impact lasts throughout the whole winter with a difference of at least $20 \%$ in ice volume and $20 \mathrm{~cm}$ in mean ice thickness (not shown).

\subsubsection{Impact of Optical Properties}

[33] In most sea ice models interactions between snow and ice with radiation are parameterized by different albedo values. On the one hand, sea ice albedo can be tuned easily to achieve acceptable results [Curry and Schramm, 2001; Miller et al., 2007; Hunke, 2010], on the other hand, the snow and sea ice albedo feedback might not be adequately represented due to inconsistencies with the radiation physics. The Delta-Eddington multiple scattering radiative transfer model prescribes the inherent optical properties: the extension coefficient, single scattering albedo and an asymmetry parameter, based on physical measurements of shape, number, and size of ice and snow grains as well as brine, gas and precipitated salts. The ensemble of these parameters representing the sea ice optical properties are enclosed in a dimensionless "standard deviation parameter" that can be used for tuning [Briegleb and Light, 2007]. The uncertainty of the standard deviation parameter allows physically consistent modifications. We performed sensitivity runs by increasing and decreasing the standard deviation parameter by 2 with a positive value referring to a decrease of albedo (under typical conditions a change of 2 standard deviations alters the albedo of ponded ice by approximately 10\%). The impact on climatological sea ice extent and volume is substantial. Decreasing the albedo decreases the August ice extent by 12\% (Figure 9a) and increasing the albedo increases the volume by $8 \%$ in March and by 33\% in September (Figure 9b).

\subsubsection{Impact of Critical Lid Depth}

[34] In our melt pond scheme we make an assumption about a critical lid depth. If the ice lid on top of a pond is thinner than the critical depth, the melt pond is active and the optical properties of ponded sea ice are applied. If the lid reaches the critical depth, the optical properties of bare ice are applied. We have chosen a critical value of $1 \mathrm{~cm}$ in the reference run and apply $5 \mathrm{~cm}$ and $2 \mathrm{~mm}$ in the sensitivity experiments. While the local exposed pond area fraction can be affected, the resulting impact on climatological ice extent (Figure 9c) and ice volume (Figure 9d) is small (less than $10 \%$ throughout the year).

\subsubsection{Impact of Maximum Pond Area}

[35] The complexity of the real ice surface topography does not generally allow the lowest ice to be completely
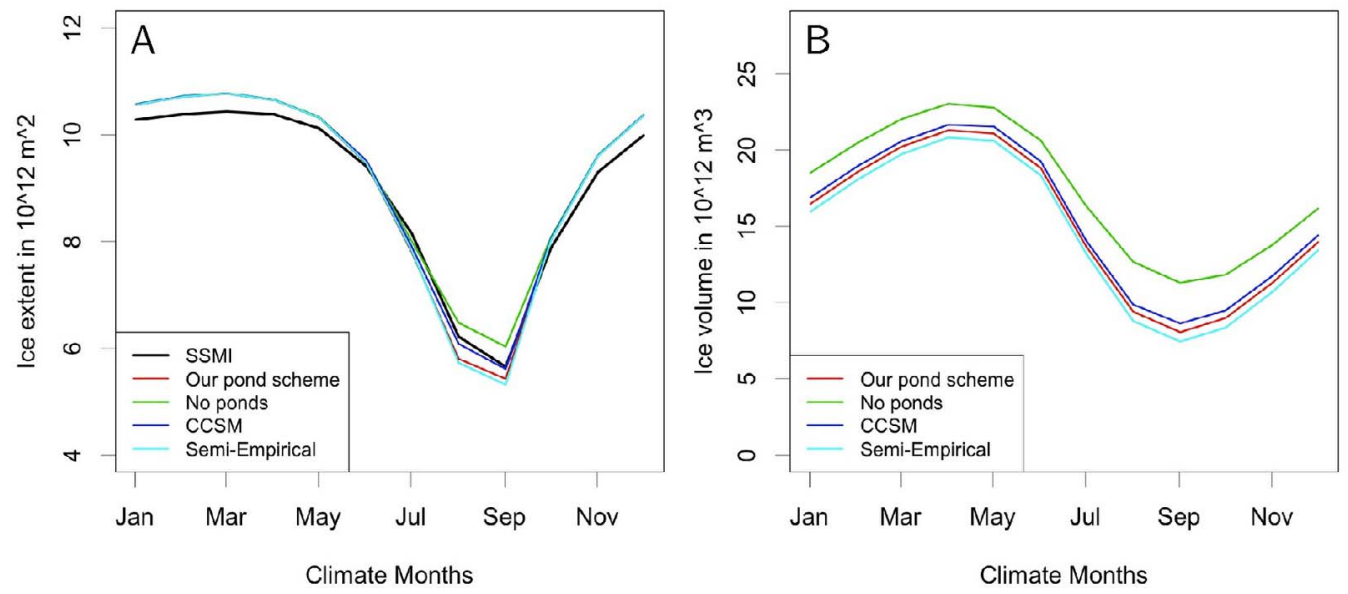

Figure 8. Impact of melt pond treatment (Our pond scheme, no ponds, an implicit pond scheme (CSSM) and a semi-empirical pond scheme) on (a) the climatology of ice extent and (b) the climatology of ice volume. 

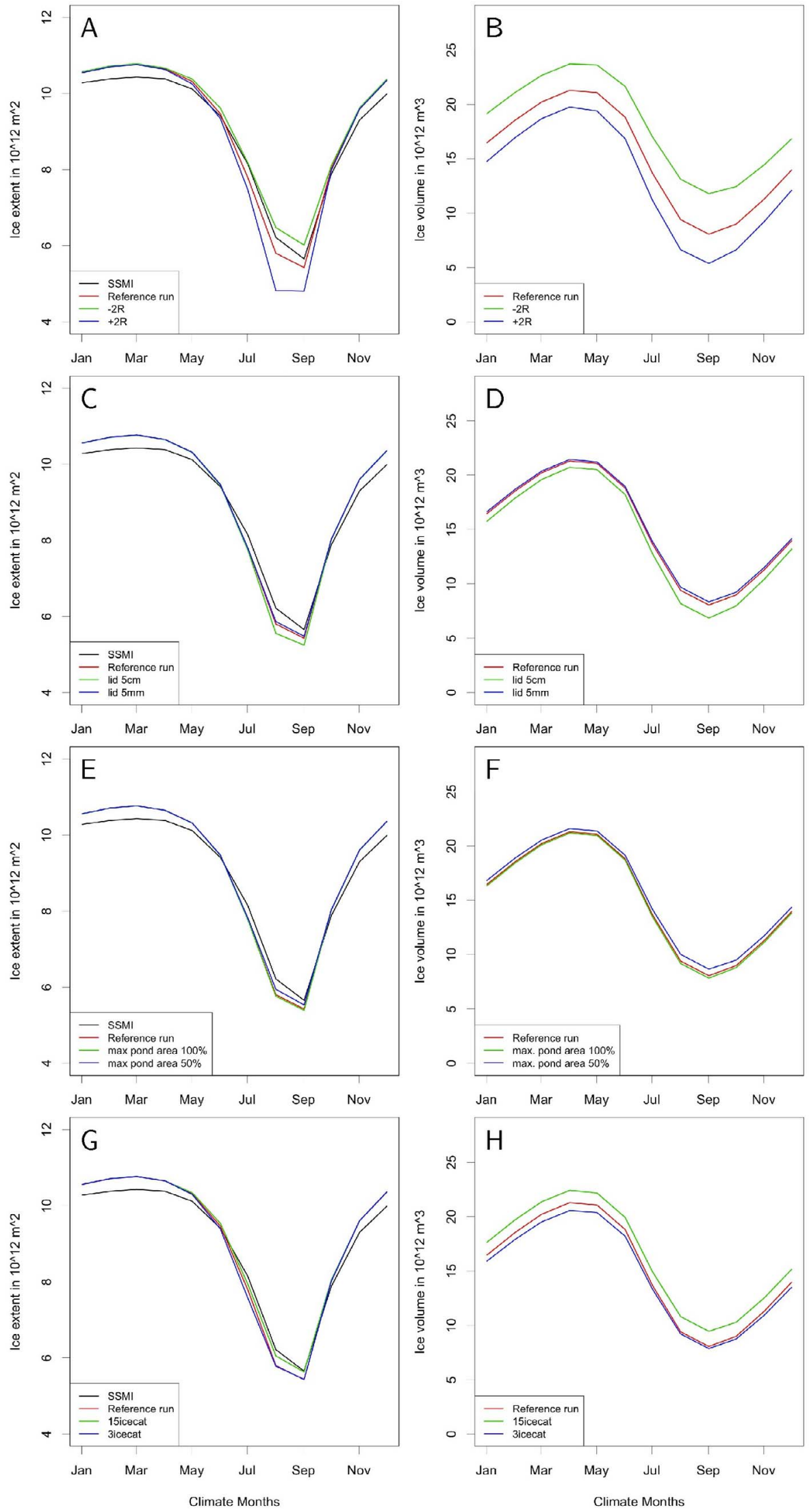

Figure 9. Sensitivity of climatological ice extent and ice volume on $(a, b)$ optical properties $(+2 R$ indicates a change by 2 standard deviations leading to an increase of albedo), (c, d) critical lid depth, (e, f) maximum pond area, and $(\mathrm{g}, \mathrm{h})$ number of ice categories. 
covered with ponds given sufficient meltwater [Lüthje et al., 2006; Scott and Feltham, 2010]. Therefore, we have to make assumptions regarding the extent to which meltwater will flow to the lowest ice. In the reference run, we prescribe the maximum area as a function of ice thickness with a value close to $80 \%$ for thin ice. Here, we test the impact if we allow first the whole ice area and second only $50 \%$ of the ice area of each thickness class to be covered with ponds.

[36] Figures 9e and 9f reveal that the impact on the climatology of ice extent and volume is relatively small. If the whole area of each ice thickness category is allowed to be covered with ponds, the summer ice extent and the ice volume decrease slightly and a reduction to $50 \%$ leads to a small increase. The impact is smaller than in the previous study of Flocco et al. [2010] in which the underestimation of summer ice thickness increased the impact of maximum pond area fraction on reducing the ice extent.

\subsubsection{Impact of Number of Ice Categories}

[37] An increase in the number of ice thickness categories generally improves results, but simulations are more expensive. Five ice categories are regarded as a good compromise and applied in the reference run. We perform sensitivity experiments with 3 and 15 ice thickness classes (see Table 2 for details). While a reduction from 5 to 3 categories has hardly any impact, an increase to 15 ice categories leads to a smaller total pond area, which causes an increase of September ice extent by $4 \%$ and of September ice volume by $28 \%$ (Figures $9 \mathrm{~g}$ and $9 \mathrm{~h}$ ). If the number of ice categories is increased, the fraction of thicker ice is increased leading to a slight decrease of pond area. Therefore, the maximum area that is allowed to be covered by ponds might be increased with increasing number of ice categories to counterbalance this effect.

\subsubsection{Impact of Snowfall}

[38] The uncertainty of snowfall is quite large in all atmospheric reanalysis products in the Polar regions [Seo et al., 2010]. Due to its impact on formation of meltwater, we include sensitivity studies with an artificial increase and decrease of snowfall rate by $33 \%$. An increase leads to a reduction of climatological August ice extent of 10\% and an ice volume reduction between 8\% (March, April) and 15\% (September) (Figures 10a and 10b). What causes the strong impact?

[39] Figures $10 \mathrm{c}-10 \mathrm{~g}$ present ice properties of one example grid point in the central Arctic (near $82^{\circ} \mathrm{N}, 151^{\circ} \mathrm{W}$ ) for the summer 2007. At the beginning of June, the snow depth varies from $25 \mathrm{~cm}$ (Run with reduced snowfall) via $40 \mathrm{~cm}$ (Reference run) to $55 \mathrm{~cm}$ (Run with increased snowfall) (Figure 10c). The snow has completely melted in all runs by mid-July. Due to differences in the available meltwater the maximum pond area varies from $28 \%$ (reduced snowfall) to $45 \%$ (increased snowfall) (Figure 10d); a similar response is found for pond depth (Figure 10e). This strongly impacts the ice thickness and ice concentration. At mid-September the ice thickness varies from $40 \mathrm{~cm}$ (increased snowfall) via $80 \mathrm{~cm}$ (reference run) to $2.4 \mathrm{~m}$ (reduced snowfall) (Figure 10f). While ice concentration only shrinks from nearly $100 \%$ to $90 \%$ in the simulation with decreased snowfall, it shrinks to nearly $10 \%$ if snowfall is increased (Figure $10 \mathrm{~g}$ ). This example documents that an increase of snowfall leads to an increase of meltwater and, thus, to an increase of pond volume and area, so that summer ice thickness and extent are reduced more strongly. This is in accordance with the findings of Scott and Feltham [2010] and is supported by the observations of Eicken et al. [2004]. During wintertime a larger snow depth causes a reduction of ice growth due its insulation effect. Both effects together are responsible for the strong impact of changes in snowfall rate on ice volume (see Figure 10b).

\subsection{The Summer of 2007}

[40] The 2007 sea ice minimum was partly the result of previous years' melting and export that created a thin ice cover vulnerable to natural variability in atmospheric and oceanic conditions, and, in 2007, an unusual combination of warm winds, promoting export and melting; clear skies, promoting surface radiative melt; and advection of heat from the North Pacific [Perovich and Richter-Menge, 2009]. In our reference simulation the September 2007 ice concentration (Figure 11a) is lower than the climatological mean (Figure 11c) in nearly all parts of the Arctic with eastern longitude. In comparison to SSM/I data, ice concentration is still overestimated north of the Laptev Sea and the Siberian Sea (Figure 11b). However, the area in which ice concentration is overestimated by more than $50 \%$ is three times smaller than in the simulation without ponds (Figure 11c) and twice smaller than in the simulation with the CCSM radiation scheme (Figure 11d). Our pond scheme causes an increase in ice melt during summer 2007. As shown in Figure 4a, the largest pond areas during early melting season occurred in 2007 . The 2007 case demonstrates the potential of a melt pond scheme to enable climate models to simulate the observed strength of sea ice decrease.

\section{Summary and Conclusion}

[41] We have developed a physically based melt pond model which simulates the evolution of melt ponds based on sea ice conditions. This model has been incorporated into the Los Alamos CICE sea ice model, the sea ice component of several IPCC climate models. Applying the atmospheric ERA-40 based Drakkar Forcing Set DFS4.1 [Brodeau et al., 2010] and ocean forcing from a Community Climate System Model climate run [Collins et al., 2006] and from ocean reanalysis data [Ferry et al., 2011], we performed standalone CICE simulations for the Arctic from 1990 to 2007.

[42] A comparison with SSM/I passive microwave satellite data and ERS radar altimetry data shows that the climatology of the reference CICE simulation with our melt pond scheme is in good agreement with observed ice extent and concentration and in reasonable agreement with observed ice thickness. Comparing time series of winter and summer ice extent reveals that the inter-annual variability is captured in our simulation, only the trend in summer ice extent is not represented. The inability of our model to simulate the trend in reduced summer ice extent, for any choice of sea ice model parameters, points to the conclusion that the reduction in ice extent is due to coupled interactions with the atmosphere and/ or ocean (moderated by the history of the ice cover) and not to missing sea ice physics alone. This coupling is, however, strongly moderated by the sea ice physics: our study shows that excluding, or inaccurately representing melt ponds artificially reduces the albedo feedback mechanism with significant leading order impacts for ice extent and thickness. In general, it is possible by altering either the atmospheric or 

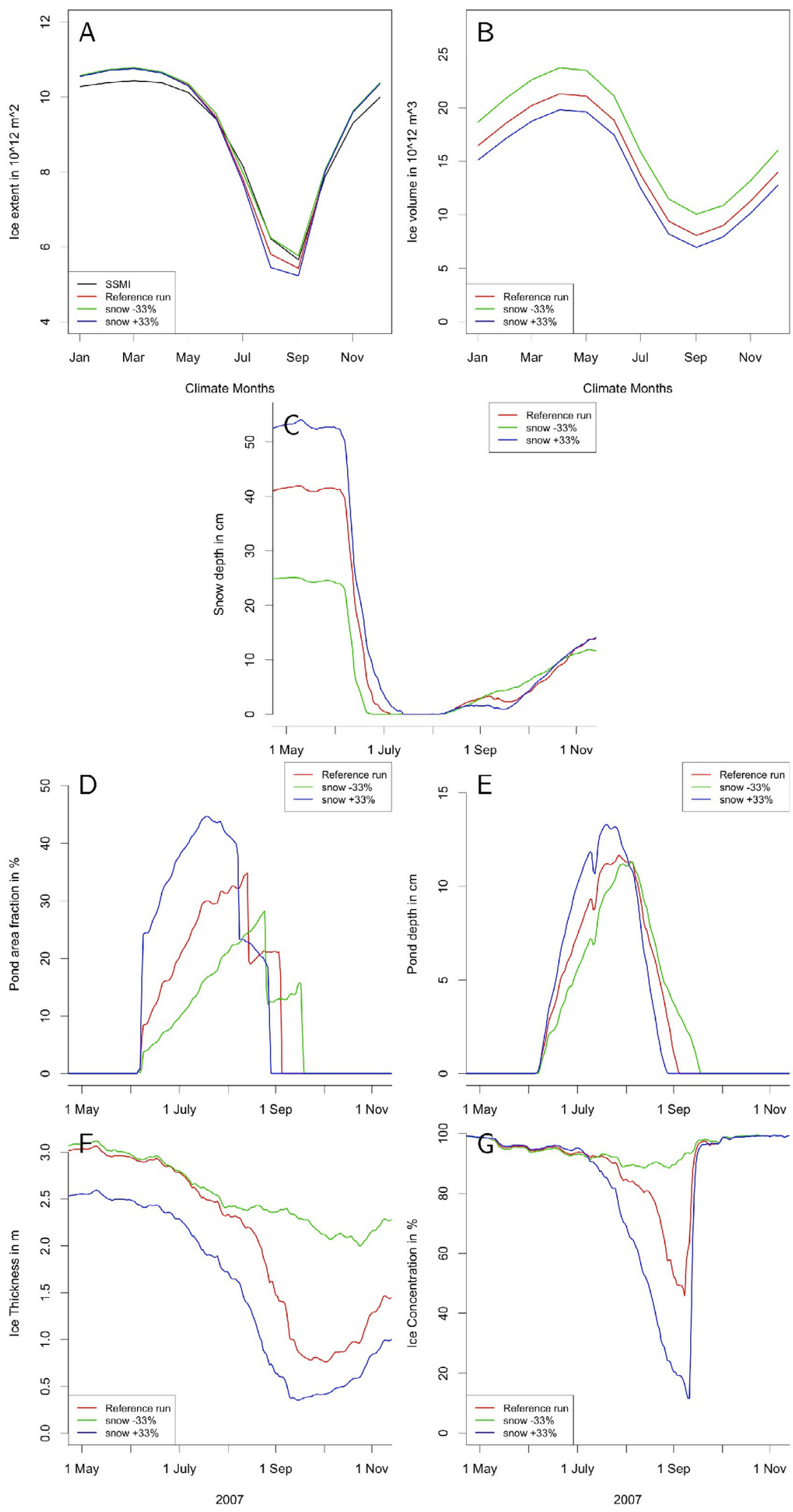

Figure 10. Impact of snowfall rate on (a) the climatology of ice extent, (b) the climatology of ice volume, and ice properties of example grid point $\left(82^{\circ} \mathrm{N}, 151^{\circ} \mathrm{W}\right)$ during summer 2007: (c) snow depth, (d) pond area (fraction of sea ice), (e) pond depth, (f) ice thickness, and (g) ice concentration. Snow depth, pond depth, and ice thickness represent means over the whole grid cell. 

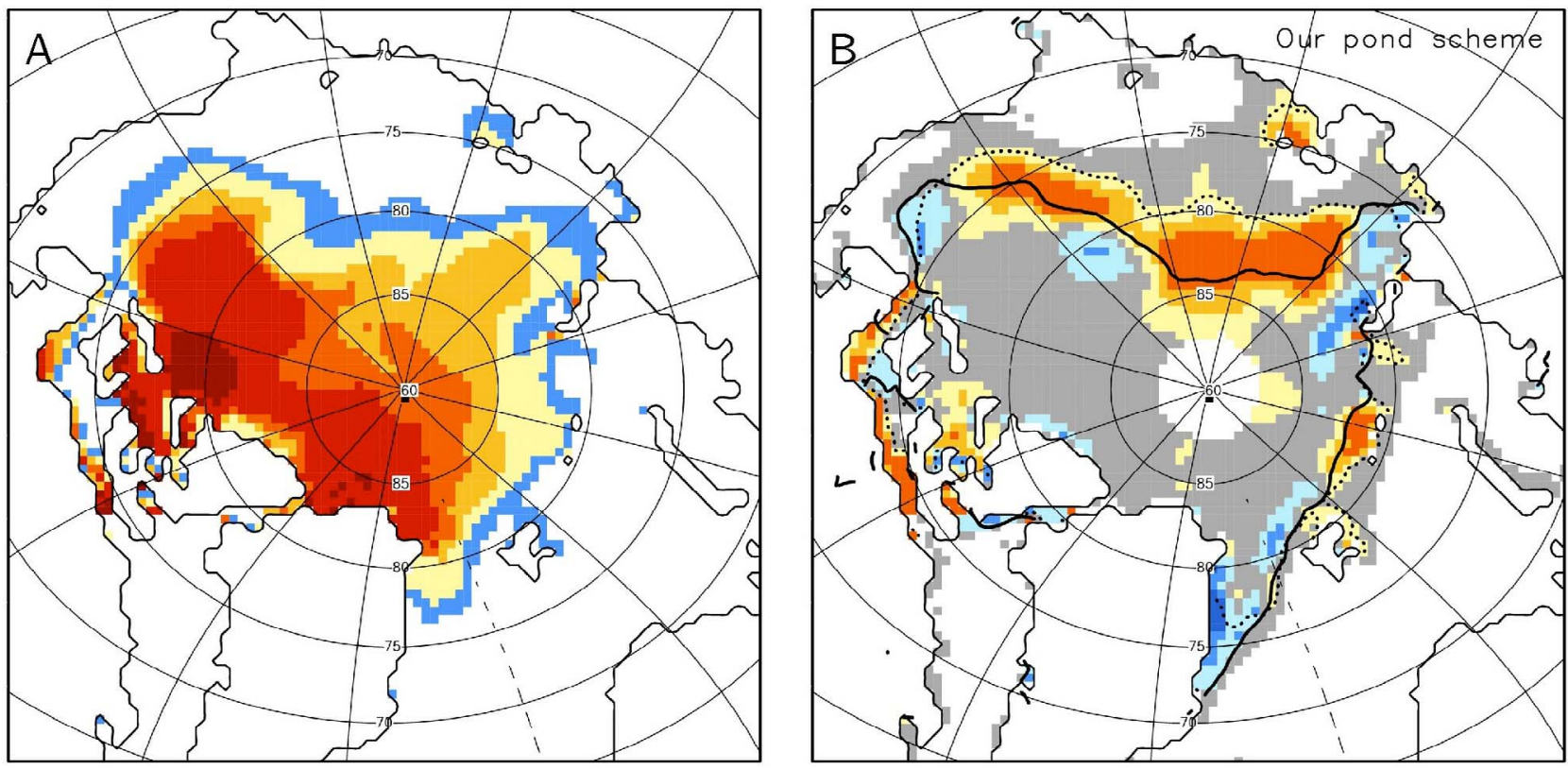

CICE minus SSMI Sept. Ice concentration in \%
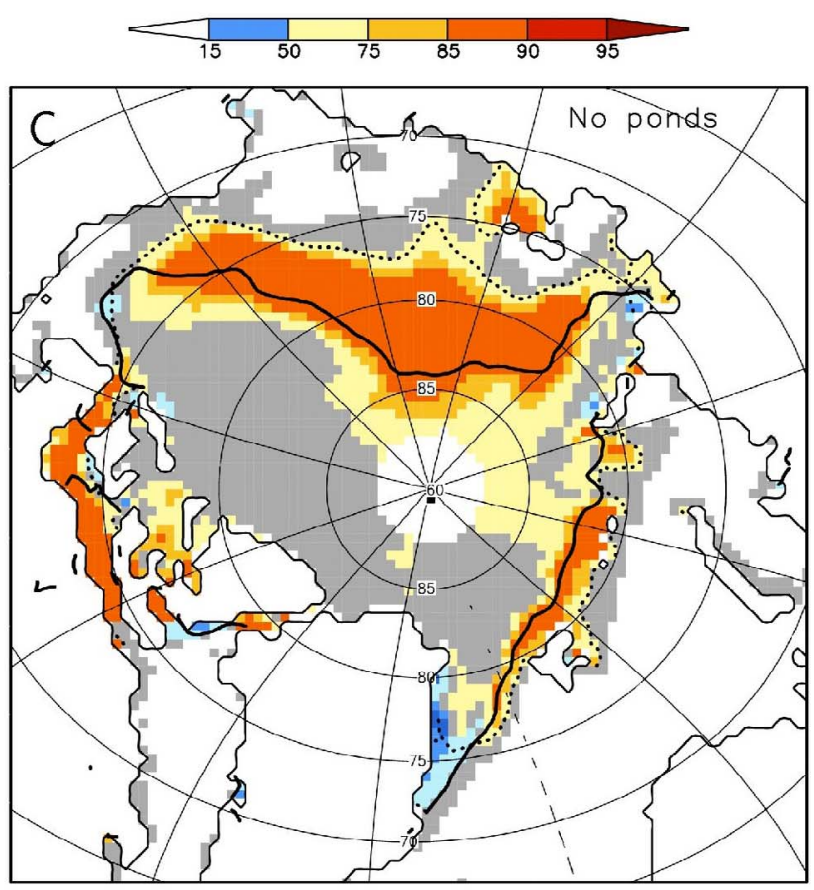

CICE minus SSMI Sept. Ice concentration in \%
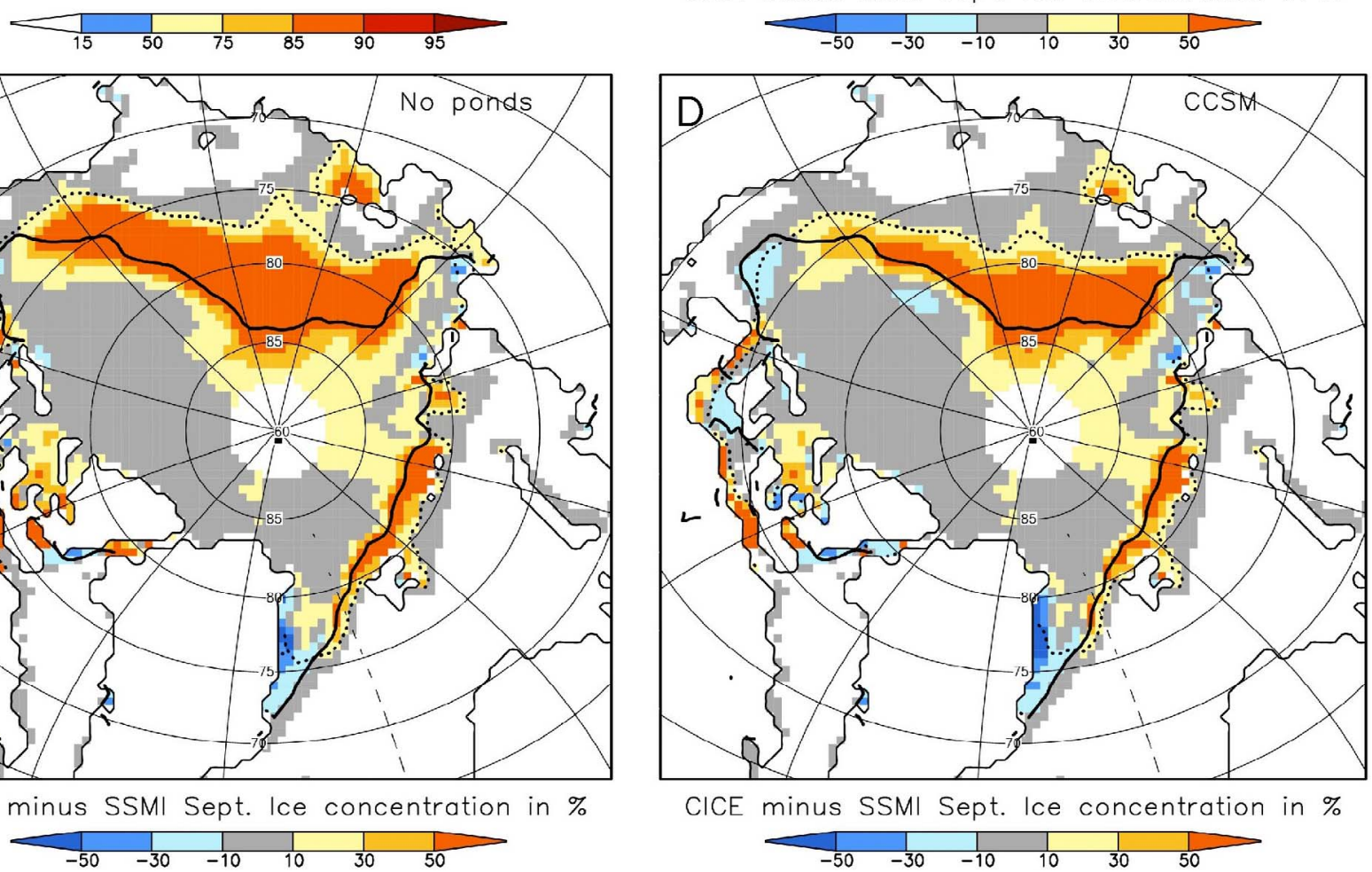

Figure 11. September 2007 ice concentration: (a) CICE reference simulation, (b) difference between CICE reference simulation and SSM/I, (c) difference between CICE simulation without ponds and SSM/I, and (d) difference between CICE simulation with CCSM radiation scheme and SSM/I. The continuous line in $b$ and $d$ represents the SSM/I ice extent (15\% contour line) and the dotted line the CICE ice extent.

oceanic forcing, within existing uncertainty, to force our model to replicate the negative trend in ice extent. We have chosen not to do this because such a choice would be arbitrary and would not shed genuine insight into the impact of melt ponds. We do find that, in general, the CICE with our melt pond scheme is able to simulate realistic sea ice evolution.
[43] In our simulation the pond season starts at the end of May, a maximum average pond coverage of nearly $20 \%$ is reached at the beginning of July and nearly all ponds are covered with an ice lid by mid-August. Locally pond area fractions of up to $60 \%$ are simulated over flat first-year ice and pond depths up to $70 \mathrm{~cm}$ over the thick multiyear ice 
north of Canada. The values and the distribution of the pond coverage are reasonable in comparison to existing observation data [Fetterer and Untersteiner, 1998] and to the climatology of Rösel et al. [2012] derived from MODIS satellite data. The annual variability of pond coverage is striking with lowest pond coverage in 1996 (the year with maximum summer ice extent) and largest pond coverage in 2007 (the year with minimum summer ice extent). This suggests that melt ponds are of increasing importance in a warmer climate and play an important role in improving Global Climate Models' ability to simulate the future Arctic sea ice decline. Unlike other treatments of melt ponds, our melt pond scheme accounts for the ice cover becoming flatter (due to an increase of first year ice) [Kwok et al., 2009] and thus has a greater pond area for the same pond volume.

[44] Simulating the three-dimensional evolution of melt ponds, Scott and Feltham [2010] showed that the snow depth at the beginning of the melt season has a strong impact on the melt pond and open ocean fraction. Our sensitivity studies with an increase and decrease of snowfall rate by $33 \%$ confirms their result that an increase of snow depth leads to an increase of meltwater and, thus, to a substantial increase of pond area. During wintertime a larger snow depth causes a reduction of ice growth due to its insulation effect. Both effects lead to a reduction ice area and volume demonstrating the importance of potential changes in precipitation for the future Arctic sea ice.

[45] The sensitivity studies reveal that our results are not strongly affected by the choice of a critical lid depth, the number of ice thickness categories or the maximum area of pond coverage in each ice category. This is a positive result strengthening the applicability of our pond scheme. In contrast, the uncertainty of the albedo (caused by the uncertainty of the optical sea ice properties) has a substantial impact on the simulated ice extent and volume. One advantage of the Delta-Eddington radiation scheme is that the uncertainty of albedo can be specified based on laboratory measurements of the standard deviation of measured optical properties [Briegleb and Light, 2007]. Our sensitivity studies reveal larger differences between the simulations with modified optical properties than between our simulations with and without melt ponds. On the one hand, the uncertainty and impact of shortwave albedo provides an easy tool to tune a sea ice model to achieve acceptable results [e.g., Curry and Schramm., 2001; Miller et al., 2007; Hunke, 2010]. On the other hand, it makes it difficult to prove whether modifications lead to real improvements. This can only be done by studies with a fully coupled ocean - sea ice - atmosphere model.

[46] Our sensitivity studies with respect to the applied melt pond scheme show a smaller impact than found in the previous study of Flocco et al. [2010]. Their underestimation of summer ice concentration and thickness increased the impact of melt ponds artificially, whereas our sensitivity studies refer to a realistic reference run. Nevertheless, the mean September ice volume is $40 \%$ higher and the ice extent $13 \%$ higher in simulations without ponds in comparison to our pond scheme. Even in wintertime the ice would be 20 to $30 \mathrm{~cm}$ thicker in average. Thus, the new simulations confirm that the incorporation of a melt pond scheme is necessary and crucial for future sea ice forecasts.
[47] Our pond scheme is computationally efficient increasing the computing time by only $10 \%$ (difference of total wall clock time between simulation with our pond scheme and simulation without ponds on linux machine using 8 processors). It is ready to be included in a coupled climate model and it is planned that it will be available in the next official release of CICE.

\section{References}

Bitz, C., and W. Lipscomb (1999), An energy-conserving thermodynamic model of sea ice, J. Geophys. Res., 104, 15,669-15,677, doi:10.1029/ 1999JC900100.

Bitz, C. M., M. M. Holland, E. C. Hunke, and R. E. Moritz (2005), Maintenance of the sea-ice edge, J. Clim., 18, 2903-2921, doi:10.1175/ JCLI3428.1.

Briegleb, B. P., and B. Light (2007), A delta-Eddington multiple scattering parameterization for solar radiation in the sea ice component of the Community Climate System Model, Tech. Note 472, Natl. Cent. for Atmos. Res., Boulder, Colo.

Brodeau, L., B. Barnier, A.-M. Treguier, T. Penduff, and S. Gulev (2010), An ERA40-based atmospheric forcing for global ocean circulation models, Ocean Modell., 31, 88-104, doi:10.1016/j.ocemod.2009.10.005.

Collins, W. D., et al. (2006), The Community Climate System Model version 3 (CCSM3), J. Clim., 19(11), 2122-2143, doi:10.1175/JCLI3761.1.

Comiso, J. (1999), Bootstrap Sea Ice Concentrations From NIMBUS-7 SMMR and DMSP SSM/I, http://nsidc.org/data/nsidc-0079.html, Natl. Snow and Ice Data Cent., Boulder, Colo.

Curry, J. A., and J. L. Schramm (2001), Applications of SHEBA/FIRE data to evaluation of snow/ice albedo parameterizations, J. Geophys Res., 106(D14), 15,345-15,355, doi:10.1029/2000JD900311.

Eicken, H., H. R. Krouse, D. Kadko, and D. K. Perovich (2002), Tracer studies of pathways and rates of melt water transport through Arctic summer sea ice, J. Geophys. Res., 107(C10), 8046, doi:10.1029/2000JC000583.

Eicken, H., T. C. Grenfell, D. K. Perovich, J. A. Richter-Menge, and K. Frey (2004), Hydraulic controls of summer Arctic pack ice albedo, J. Geophys. Res., 109, C08007, doi:10.1029/2003JC001989.

Eisenman, I., N. Untersteiner, and J. S. Wettlaufer (2007), On the reliability of simulated Arctic sea ice in global climate models, Geophys. Res. Lett., 34, L10501, doi:10.1029/2007GL029914.

Feltham, D. L., N. Untersteiner, J. S. Wettlaufer, and G. M. Worster (2006), Sea ice is a mushy layer, Geophys. Res. Lett., 33, L14501, doi:10.1029/ 2006GL026290.

Ferry, N., S. Masina, A. Storto, K. Haines, M. Valdivieso, B. Barnier, and J.-M. Molines (2011), Product user manual GLOBAL-REANALYSISPHYS-001-004-a and b, MyOcean, Eur. Comm., Brussels.

Fetterer, F., and N. Untersteiner (1998), Observations of melt ponds on Arctic sea ice, J. Geophys. Res., 103, 24,821-24,835, doi:10.1029/ 98JC02034.

Flocco, D., and D. L. Feltham (2007), A continuum model of melt pond evolution on Arctic sea ice, J. Geophys. Res., 112, C08016, doi:10.1029/ 2006JC003836.

Flocco, D., D. L. Feltham, and A. K. Turner (2010), Incorporation of a physically based melt pond scheme into the sea ice component of a climate model, J. Geophys. Res., 115, C08012, doi:10.1029/2009JC005568.

Giles, K. A., S. W. Laxon, D. J. Wingham, D. W. Wallis, W. B. Krabill, C. J. Leuschen, D. McAdoo, S. S. Manizade, and R. K. Raney (2007), Combined airborne laser and radar altimeter measurements over the Fram Strait in May 2002, Remote Sens. Environ., 111, 182-194, doi:10.1016/j.rse.2007.02.037.

Giles, K. A., S. W. Laxon, and A. L. Ridout (2008), Circumpolar thinning of Arctic sea ice following the 2007 record ice extent minimum, Geophys. Res. Lett., 35, L22502, doi:10.1029/2008GL035710.

Golden, K. M., H. Eicken, A. L. Heaton, J. Miner, D. J. Pringle, and J. Zhu (2007), Thermal evolution of permeability and microstructure in sea ice, Geophys. Res. Lett., 34, L16501, doi:10.1029/2007GL030447.

Grenfell, T., and G. Maykut (1977), The optical properties of ice and snow in the Arctic Basin, J. Glaciol., 18, 445-463.

Hibler, W. D., III (1979), A dynamic thermodynamic sea ice model, J. Phys. Oceanogr., 9, 815-846, doi:10.1175/1520-0485(1979) $009<0815$ :ADTSIM $>2.0 . \mathrm{CO} ; 2$

Holland, M. M., D. A. Bailey, B. P. Briegleb, B. Light, and E. Hunke (2012), Improved sea ice shortwave radiation physics in CCSM4: The impact of melt ponds and aerosols on Arctic sea ice, J. Clim., 25(5), 1413-1430, doi:10.1175/JCLI-D-11-00078.1.

Hunke, E. C. (2010), Thickness sensitivities in the CICE sea ice model, Ocean Modell., 34, 137-149, doi:10.1016/j.ocemod.2010.05.004. 
Hunke, E. C., and J. K. Dukowicz (1997), An elastic viscous plastic model for sea ice dynamics, J. Phys. Oceanogr., 27, 1849-1867, doi:10.1175 1520-0485(1997)027<1849:AEVPMF>2.0.CO;2.

Intergovernmental Panel on Climate Change (2007), Climate Change 2007: The Physical Science Basis. Contribution to Working Group I to the Fourth Assessment Report of the Intergovernmental Panel on Climate Change, edited by S. Solomon et al., Cambridge Univ. Press, U. K.

Kern, S., L. Kaleschke, and D. A. Clausi (2003), A comparison of two 85-GHz SSM/I ice concentration algorithms with AVHRR and ERS-2 SAR imagery, IEEE Trans. Geosci. Remote Sens., 41(10), 2294-2306, doi:10.1109/TGRS.2003.817181.

Kwok, R., G. F. Cunningham, M. Wensnahan, I. Rigor, H. J. Zwally, and D. Yi (2009), Thinning and volume loss of the Arctic Ocean sea ice cover: 2003-2008, J. Geophys. Res., 114, C07005, doi:10.1029/ 2009JC005312.

Laxon, S. W., N. Peacock, and D. Smith (2003), High interannual variability of sea ice thickness in the Arctic region, Nature, 425, 947-950 doi: 10.1038 /nature 02050

Lipscomb, W. H., E. C. Hunke, W. Maslowski, and J. Jakacki (2007), Ridging, strength, and stability in high-resolution sea ice models, J. Geophys. Res., 112, C03S91, doi:10.1029/2005JC003355.

Lüthje, M., D. L. Feltham, P. D. Taylor, and M. G. Worster (2006), Modeling the summertime evolution of sea-ice melt ponds, J. Geophys. Res., 111, C02001, doi:10.1029/2004JC002818.

Madec, G. (2008), NEMO ocean engine, Notes Pole Model. 27, Inst. PierreSimon Laplace, Paris.

Markus, T., D. J. Cavalieri, M. A. Tschudi, and A. Ivanoff(2003), Comparison of aerial video and Landsat 7 data over ponded sea ice, Remote Sens. Environ., 86, 458-469, doi:10.1016/S0034-4257(03)00124-X.

Maslanik, J., S. Drobot, C. Fowler, G. McPhee, W. Emery, and R. Barry (2007), On the Arctic climate paradox and the continuing role of atmospheric circulation in affecting sea ice conditions, Geophys. Res. Lett., 34, L03711, doi:10.1029/2006GL028269.

Maykut, G. A., and N. Untersteiner (1971), Some results from a timedependent thermodynamic model of sea ice, J. Geophys. Res., 76 , 1550-1575, doi:10.1029/JC076i006p01550.

Meier, W. N. (2005), Comparison of passive microwave ice concentration algorithm retrievals with AVHRR imagery in Arctic peripheral seas, IEEE Trans. Geosci. Remote Sens., 43(6), 1324-1337, doi:10.1109/ TGRS.2005.846151.

Miller, P. A., S. W. Laxon, and D. L. Feltham (2007), Consistent and contrasting decadal Arctic sea ice thickness predictions from a highly optimized sea ice model, J. Geophys. Res., 112, C07020, doi:10.1029/2006JC003855.

National Snow and Ice Data Center (1998), Submarine Upward Looking Sonar Ice Draft Profile Data and Statistics, http://nsidc.org/data/g01360.html 1998, Boulder, Colo.

Perovich, D. K. (2005), On the aggregate-scale partitioning of solar radiation in Arctic sea ice during the Surface Heat Budget of the Arctic Ocean (SHEBA) field experiment, J. Geophys. Res., 110, C03002, doi:10.1029/ 2004JC002512.

Perovich, D. K., and J. A. Richter-Menge (2009), Loss of sea ice in the Arctic, Annu. Rev. Mar. Sci., 1, 417-441, doi:10.1146/annurev.marine. 010908.163805
Perovich, D. K., and W. B. Tucker III (1997), Arctic sea-ice conditions and the distribution of solar radiation during summer, Ann. Glaciol., 25, 445-450.

Perovich, D. K., W. B. Tucker III, and K. A. Ligett (2002), Aerial observations of the evolution of ice surface conditions during summer, J. Geophys. Res., 107(C10), 8048, doi:10.1029/2000JC000449.

Perovich, D. K., B. Light, H. Eicken, K. F. Jones, K. Runciman, and S. V. Nghiem (2007), Increasing solar heating of the Arctic Ocean and adjacent seas, 1979-2005: Attribution and role in the 5 ice-albedo feedback, Geophys. Res. Lett., 34, L19505, doi:10.1029/2007GL031480.

Perovich, D. K., T. C. Grenfell, B. Light, B. C. Elder, J. Harbeck, C. Polashenski, W. B. Tucker III, and C. Stelmach (2009), Transpolar observations of the morphological properties of Arctic sea ice, J. Geophys. Res., 114, C00A04, doi:10.1029/2008JC004892.

Perovich, D. K., J. A. Richter-Menge, K. F. Jones, B. Light, B. C. Elder, C. Polashenski, D. Laroche, T. Markus, and R. Lindsay (2011), Arctic sea-ice melt in 2008 and the role of solar heating, Ann. Glaciol., 52(57), 355-359, doi:10.3189/172756411795931714

Polashenski, C., D. K. Perovich, and Z. Courville (2012), The mechanisms of sea ice melt pond formation and evolution, J. Geophys. Res., 117, C01001, doi:10.1029/2011JC007231.

Rösel, A., L. Kaleschke, and G. Birnbaum (2012), Melt ponds on Arctic sea ice determined from MODIS satellite data using an artificial neural network, Cryosphere, 6, 431-446, doi:10.5194/tc-6-431-2012.

Röske, F. (2005), Global oceanic heat and fresh water forcing datasets based on ERA-40 and ERA-15, Rep. Earth Syst. Sci. 13, Max Planck Inst. for Meteorol., Hamburg, Germany.

Rothrock, D. A. (1975), The energetics of the plastic deformation of pack ice by ridging, J. Geophys. Res., 80, 4514 4519, doi:10.1029/JC080i033p04514.

Schweiger, A., R. Lindsay, J. Zhang, M. Steele, H. Stern, and R. Kwok (2011), Uncertainty in modeled Arctic sea ice volume, J. Geophys. Res., 116, C00D06, doi:10.1029/2011JC007084.

Scott, F., and D. L. Feltham (2010), A model of the three-dimensional evolution of Arctic melt ponds on first-year and multiyear sea ice, J. Geophys. Res., 115, C12064, doi:10.1029/2010JC006156.

Seo, K.-W., D. Ryu, B.-M. Kim, D. E. Waliser, B. Tian, and J. Eom (2010), GRACE and AMSR-E-based estimates of winter season solid precipitation accumulation in the Arctic drainage region, J. Geophys. Res., 115, D20117, doi:10.1029/2009JD013504

Skyllingstad, E. D., C. A. Paulson, and D. Perovich (2009), Simulation of melt pond evolution on level ice, J. Geophys. Res., 114, C12019, doi:10.1029/2009JC005363.

Stroeve, J., M. M. Holland, W. Meier, T. Scambos, and M. Serreze (2007), Arctic sea ice decline: Faster than forecast, Geophys. Res. Lett., 34 L09501, doi:10.1029/2007GL029703.

Taylor, P. D., and D. L. Feltham (2004), A model of melt pond evolution on sea ice, J. Geophys. Res., 109, C12007, doi:10.1029/2004JC002361.

Thorndike, A. S., D. A. Rothrock, G. A. Maykut, and R. Colony (1975), The thickness distribution of sea ice, J. Geophys. Res., 80, 4501-4513, doi:10.1029/JC080i033p04501

Tschudi, M. A., J. A. Maslanik, and D. K. Perovich (2008), Derivation of melt pond coverage on Arctic sea ice using Modis observation, Remote Sens. Environ., 112, 2605-2614, doi:10.1016/j.rse.2007.12.009. 